\title{
Características nutricionais e utilização do resíduo de batata-doce em dietas de frangos de crescimento lento ${ }^{1}$
}

\author{
Nutritional characteristics and use the residue of sweet potato in slow growth \\ broiler diets
}

\author{
PARENTE, Iberê Pereira ${ }^{2} *$; RODRIGUES, Kênia Ferreira ${ }^{3}$; VAZ, Roberta Gomes \\ Marçal Vieira ${ }^{3}$; SOUSA, Joana Patrícia Lira ${ }^{2}$; SANTOS NETA, Ernestina Ribeiro dos ${ }^{4}$; \\ ALBINO, Luiz Fernando Teixeira ${ }^{5}$; SIQUEIRA, Jefferson Costa de ${ }^{6}$, PAIVA, Joseilson \\ Alves de
}

\footnotetext{
${ }^{1}$ Parte da dissertação de mestrado do primeiro autor.

${ }^{2}$ Universidade Federal do Tocantins, Programa de Pós Graduação em Ciência Animal Tropical, Araguaína, Tocantins, Brasil.

${ }^{3}$ Universidade Federal do Tocantins, Departamento de Zootecnia, Araguaína, Tocantins, Brasil.

${ }^{4}$ Universidade Federal Rural da Amazônia, Departamento de Zootecnia, Parauapebas, Pará, Brasil.

${ }^{5}$ Universidade Federal de Viçosa, Departamento de Zootecnia, Viçosa, Minas Gerais, Brasil.

${ }^{6}$ Universidade Federal do Maranhão, Centro de Ciências Agrárias e Ambientais, Chapadinha, Maranhão, Brasil.

${ }^{7}$ Universidade Federal do Tocantins, Departamento de Química, Araguaína, Tocantins, Brasil.

*Endereço para correspondência: iberepereira@hotmail.com
}

\section{RESUMO}

Foram realizados três experimentos, para determinar o valor energético e nutricional do resíduo da produção de etanol a partir da batatadoce (RBD) e a sua utilização em dietas para frangos de crescimento lento. No primeiro experimento foi realizado um ensaio metabólico a fim de determinar a energia metabolizável aparente (EMA) e a corrigida para o balanço de nitrogênio (EMAn), bem como os coeficientes de metabolizabilidade aparente do resíduo, utilizando o método de coleta total de excretas, num delineamento inteiramente casualizado, com dois tratamentos: ração referência e ração teste $(70 \%$ ração referência $+30 \%$ de inclusão do resíduo da batata-doce), quatro repetições e dez frangos de crescimento lento por unidade experimental. O RBD apresentou: $24,64 \%$ de proteína bruta, $2732 \mathrm{kcal} / \mathrm{kg}$ e $2547 \mathrm{kcal} / \mathrm{kg}$ EMA e EMAn na matéria natural. Os demais experimentos foram realizados para avaliar níveis de inclusão $(0 \%, 6 \%, 12 \%$ e $18 \%)$ do RBD em dietas de aves de crescimento lento, em um delineamento inteiramente casualizado, com quatro tratamentos e cinco repetições e 10 aves por unidade experimental, avaliando o desempenho e metabolismo das rações. Os níveis de inclusão não afetaram o consumo de ração, mas houve redução no ganho de peso (GP) e piora na conversão alimentar (CA). Os coeficientes de metabolizabilidade do nitrogênio e matéria mineral apresentaram efeito quadrático com pontos máximos de $6,38 \%$ e $5,17 \%$ respectivamente. O RBD pode ser incluído nas rações de aves de crescimento lento até o nível de 1,041\%.

Palavras-chave: alimentos alternativos, aves alternativas, desempenho, metabolismo

\section{SUMMARY}

Three experiments were conducted in the poultry sector of the Federal University of Tocantins - Campus of Araguaina, to determine the energy and nutritional values of the residue of ethanol production from sweet potato (RBD) and its use in slow growth broiler diets. In the first experiment was conducted a metabolism trial to determine the apparent metabolizable energy (AME) and corrected for nitrogen balance (AMEn) and apparent metabolizable coefficients of the residue using the method of 
total excreta collection, in a completely randomized design with two treatments: basal diet and test diet $(70 \%$ reference diet $+30 \%$ inclusion of the residue of sweet potato) four replications and ten birds per experimental unit. The RBD used showed: $24.64 \%$ of crude protein (CP), and $2732 \mathrm{kcal} / \mathrm{kg}$ and $2547 \mathrm{kcal} /$ $\mathrm{kg}$ as the determined values for AME and AMEn on the natural material respectively. The others experiments were conducted to evaluate the inclusion $(0 \%, 6 \%, 12 \%$ and $18 \%)$ of RBD in slow growth poultry diets, evaluating the performance characteristics and metabolism. The inclusion levels did not affect feed intake, but there was a reduction in weight gain(WG) and worse feed conversion(FC). The coefficients of metabolizable nitrogen and mineral matter presented quadratic performance with maximum points from $6.38 \%$ and $5.17 \%$ respectively. The RBD can be included in slow growth poultry diets to the level of $1,041 \%$.

Keywords: alternative food, alternatives poultry, performance, metabolism

\section{INTRODUÇÃO}

O Brasil tem conquistado posição de destaque na produção e exportação de frangos, devido às criações em sistemas intensivos, com linhagens geneticamente melhoradas, que apresentam bons índices de desempenho. Entretanto, o rápido ganho de peso e baixa conversão alimentar dessas aves, geram desconfiança entre os consumidores, por acreditarem na utilização de produtos prejudiciais a saúde do consumidor final, o ser humano (FAO, 2008).

A criação alternativa de frangos do tipo caipira tem aumentado na última década, no Brasil e no mundo, tornando-se lucrativa e interessante para pequenos e médios produtores rurais, os quais necessitam aumentar a renda familiar para poderem permanecer nas suas propriedades. $\mathrm{O}$ crescimento desta atividade deve-se ao maior interesse do consumidor pela qualidade dos alimentos em suas dietas, e pelo consumo de carne de frango com sabor diferenciado e menor teor de gordura (TAKAHASHI et al., 2006; RIZZI et al., 2007).

$\mathrm{Na}$ exploração da avicultura industrial, alternativa, ou caipira, que utilize como base alimentar a ração concentrada, o custo da alimentação representa cerca de $70 \%$ do custo total, devido à disponibilidade do milho e farelo de soja sofrerem variações em função da região e época do ano, gerando oscilações nos preços dessas matérias primas. Assim, uma das formas de diminuir os custos da alimentação é a utilização de alimentos alternativos. (NASCIMENTO et al., 2005; PASCOAL et al., 2006; PELIZER et al., 2007; SANTOS NETA et al., 2011; SOUSA et al., 2012).

Segundo Silveira et al. (2008), é possível obter alta produtividade com a batata-doce, cerca de 40 toneladas por hectare, média superior a $27 \%$ (vinte e sete por cento) de amido, produção média de 170 (cento e setenta) litros de etanol por tonelada, com resíduo de aproximadamente 300 (trezentos) quilos, com índice superior a 16\% (dezesseis por cento) de proteína.

O resíduo da produção de etanol, que provem da batata doce pode ser fonte alternativa alimentar para aves caipira, pois apresenta índice superior a $16 \%$ (dezesseis por cento) de proteína, podendo ser utilizado para industrialização de rações e tornar viável a implantação da tecnologia desenvolvida em escala comercial (SILVEIRA et al., 2008).

Objetivou-se determinar a composição bromatológica, os valores energéticos, os coeficientes de metabolização do resíduo de batata-doce, e o melhor nível de utilização desse resíduo em dietas iniciais de aves de crescimento lento. 
Rev. Bras. Saúde Prod. Anim., Salvador, v.15, n.2, p.470-483 abr./jun., 2014 http://www.rbspa.ufba.br ISSN 15199940

\section{MATERIAL E MÉTODOS}

Três experimentos foram realizados no setor de avicultura da Escola de Medicina Veterinária e Zootecnia (EMVZ) - Campus de Araguaína da Universidade Federal do Tocantins (UFT).

No primeiro experimento foram utilizadas 80 aves de crescimento lento Redbro Cou Nu, com 30 dias de idade e peso médio de $540 \mathrm{~g} \pm 24 \mathrm{~g}$, para estimar a energia metabolizável aparente (EMA), a energia metabolizável aparente corrigida para o balanço de nitrogênio (EMAn) e os coeficientes de metabolização da matéria seca (CMMS), da proteína bruta (CMPB), do extrato etéreo (CMEE) e da energia bruta (CMEB) do resíduo da batata-doce, utilizando a técnica de coleta total de excretas de acordo com Sakomura \& Rostagno (2007).

Os pintainhos foram criados em baterias metálicas, equipadas com comedouros e bebedouros tipo calha, sistema de iluminação para aquecimento das aves e bandejas metálicas colocadas sob as gaiolas para retirada das excretas. $\mathrm{O}$ galpão em que as aves foram alojadas possuía cortinas laterais, que foram manejadas de acordo com a temperatura e o comportamento das aves.

No $30^{\circ}$ dia as aves foram pesadas e distribuídas aleatoriamente nas gaiolas experimentais e receberam as rações a serem testadas. $\mathrm{O}$ delineamento experimental foi inteiramente casualizado, com dois tratamentos, quatro repetições e dez aves por unidade experimental, sendo os tratamentos: Ração referência a base de milho e farelo de soja para atender as exigências nutricionais para essa fase, segundo Rostagno et al. (2011) (Tabela 1); 70\% ração referência $+30 \%$ alimento (resíduo da batata-doce).
Tabela 1.Composição centesimal e calculada da ração referência (base na matéria natural)

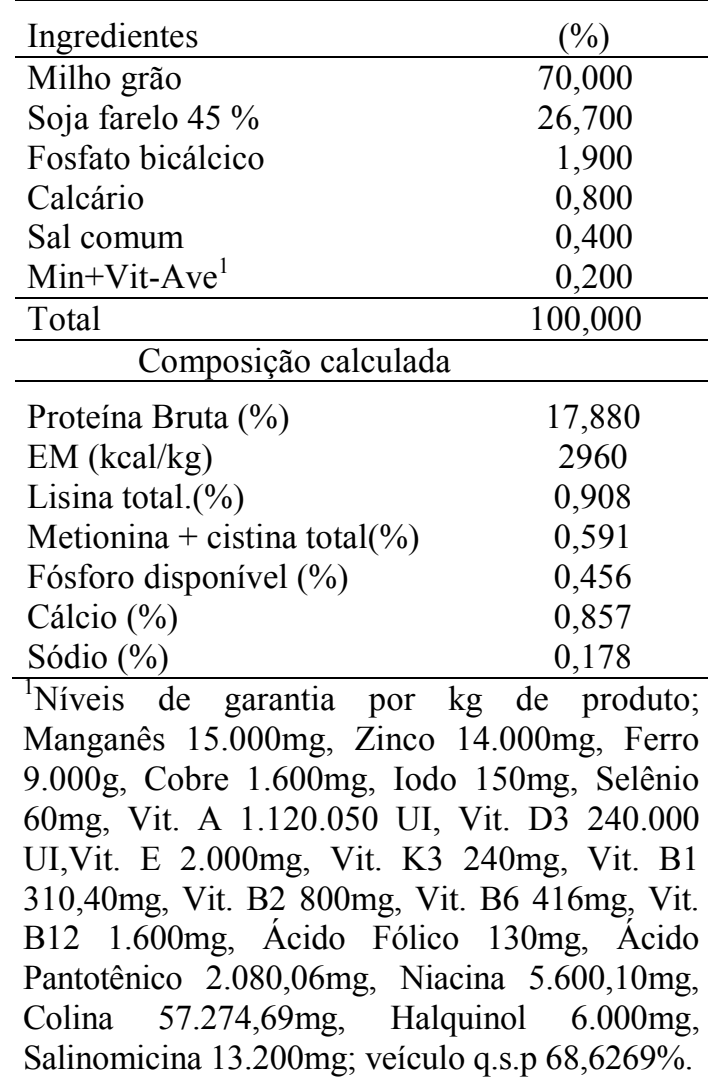

O período experimental foi de sete dias, sendo quatro dias de adaptação às rações, seguidos de três dias de coleta total de excretas (RODRIGUES et al., 2005; ÁVILA et al., 2006).

Durante o período de coleta, bandejas revestidas com plástico foram dispostas sob o piso de cada gaiola. As coletas foram realizadas diariamente duas vezes ao dia (8 e 16h.) para evitar fermentações, de acordo com Rodrigues et al. (2005). Após cada coleta as excretas foram acondicionadas em sacos plásticos, devidamente identificadas, e armazenadas em freezer, para posteriores análises. No final do período experimental, foram determinadas as quantidades de ração consumida e o total de excretas produzidas. 
Para as análises as excretas foram descongeladas à temperatura ambiente, homogeneizadas e retiradas alíquotas, que foram colocadas em estufa de ventilação forçada a $55^{\circ} \mathrm{C}$, por 72 horas, a fim de promover a pré-secagem. Em seguida, as amostras foram processadas em moinho tipo faca, com peneira de $1 \mathrm{~mm}$ e encaminhadas ao laboratório, junto com amostras das rações experimentais.

As análises laboratoriais foram realizadas no Laboratório de Bromatologia da UFT, de acordo com as técnicas descritas por Silva \& Queiroz (2006) e foram realizadas análises de matéria seca (MS), proteína bruta (PB), energia bruta (EB), extrato etéreo (EE) e fibra em detergente neutro (FDN), dos alimentos, das rações experimentais, bem como das excretas.

Após as análises dos materiais coletados (excretas e rações) foram determinados os valores de energia metabolizável aparente (EMA) e energia metabolizável aparente corrigida para o balanço de nitrogênio (EMAn) segundo Matterson et al. (1965) e os coeficientes de metabolização aparente da matéria seca (CMAMS), proteína bruta (CMAPB) e extrato etéreo (CMAEE) do resíduo da batata-doce.
No segundo experimento foram utilizados 200 pintos de crescimento lento Redbro Cou Nu, com oito dias de idade e peso médio inicial de $96 \mathrm{~g} \pm$ $1,5 \mathrm{~g}$, criados em condições semelhantes ao primeiro experimento.

$\mathrm{Na}$ primeira semana, as aves receberam ração única e a partir do sétimo dia foram pesadas e distribuídas homogeneamente nas parcelas experimentais.

$\mathrm{O}$ delineamento experimental foi inteiramente casualizado com quatro tratamentos, cinco repetições e dez aves por unidade experimental. Os tratamentos consistiram de níveis crescentes de inclusão do resíduo da batata-doce (RBD) $(0 \%, 6 \%, 12 \%$ e $18 \%)$. Para formulação das rações experimentais utilizou-se o valor energético do resíduo obtido no experimento 1. A composição dos ingredientes utilizados na formulação das rações experimentais foi determinada no Laboratório de Nutrição Animal da UFT (Tabela 2), com exceção dos valores energéticos do milho e do farelo de soja que foram determinados por Rostagno et al. (2011).

As rações foram formuladas para atender as exigências nutricionais das aves segundo Rostagno et al. (2011), conforme descrito na Tabela 3.

Tabela 2. Composição dos ingredientes utilizados nas rações experimentais (com base na matéria natural)

\begin{tabular}{lccc}
\hline Nutriente & Milho & Farelo de Soja & Resíduo de batata-doce \\
\hline Proteína bruta (\%) & 8,26 & 45,32 & 24,64 \\
EM (kcal/kg) & 3381 & 2256 & 2547 \\
Fibra Bruta (\%) & 1,73 & 5,41 & 9,34 \\
Lisina total.(\%) & 0,24 & 2,77 & 0,11 \\
Metionina + cistina total (\%) & 0,36 & 1,27 & 0,09 \\
Fósforo disponível (\%) & 0,08 & 0,18 & 0,15 \\
Cálcio (\%) & 0,03 & 0,24 & 0,37 \\
Sódio (\%) & 0,02 & 0,02 & ND $^{1}$ \\
\hline
\end{tabular}

${ }^{\mathrm{T}}$ Não determinado. 
Rev. Bras. Saúde Prod. Anim., Salvador, v.15, n.2, p.470-483 abr./jun., 2014 http://www.rbspa.ufba.br ISSN 15199940

Tabela 3. Composição percentual e química das rações experimentais (base na matéria natural)

\begin{tabular}{|c|c|c|c|c|}
\hline \multirow{2}{*}{ Ingredientes } & \multicolumn{4}{|c|}{ Níveis de resíduo da batata-doce $(\%)$} \\
\hline & 0 & 6 & 12 & 18 \\
\hline Milho grão & 70,000 & 66,740 & 63,000 & 58,200 \\
\hline Soja farelo & 26,700 & 24,000 & 21,200 & 19,117 \\
\hline Resíduo da batata-doce & 0,000 & 6,000 & 12,000 & 18,000 \\
\hline Fosfato bicálcico & 1,900 & 1,892 & 1,890 & 1,880 \\
\hline Óleo de soja & 0,000 & 0,000 & 0,575 & 1,500 \\
\hline Calcário & 0,800 & 0,765 & 0,728 & 0,693 \\
\hline Sal comum & 0,400 & 0,403 & 0,407 & 0,410 \\
\hline Min+Vit-aves ${ }^{1}$ & 0,200 & 0,200 & 0,200 & 0,200 \\
\hline Total & 100,000 & 100,000 & 100,000 & 100,000 \\
\hline \multicolumn{5}{|c|}{ Composição nutricional calculada } \\
\hline Proteína bruta $(\%)$ & $17,88(18,37)^{2}$ & $17,86(19,03)$ & $17,77(18,90)$ & $17,90(18,34)$ \\
\hline EM (kcal/kg) & 2960 & 2950 & 2960 & 2980 \\
\hline Fibra Bruta (\%) & 2,65 & 3,01 & 3,35 & 3,722 \\
\hline $\operatorname{FDN}(\%)^{2}$ & 14,14 & 17,26 & 19,00 & 24,63 \\
\hline Lisina total. $(\%)$ & 0,908 & 0,832 & 0,752 & 0,689 \\
\hline Metionina + cistina total $(\%)$ & 0,591 & 0,551 & 0,507 & 0,469 \\
\hline Fósforo disponível (\%) & 0,456 & 0,456 & 0,456 & 0,456 \\
\hline Cálcio $(\%)$ & 0,857 & 0,857 & 0,857 & 0,857 \\
\hline Sódio (\%) & 0,178 & 0,178 & 0,178 & 0,178 \\
\hline
\end{tabular}

${ }^{1}$ Níveis de garantia por kg de produto; Manganês $15.000 \mathrm{mg}$, Zinco $14.000 \mathrm{mg}$, Ferro $9.000 \mathrm{~g}$, Cobre $1.600 \mathrm{mg}$, Iodo $150 \mathrm{mg}$, Selênio 60mg, Vit. A 1.120 .050 UI, Vit. D3 240.000 UI,Vit. E 2.000mg, Vit. K3 240mg, Vit. B1 310,40mg, Vit. B2 800mg, Vit. B6 416mg, Vit. B12 1.600mg, Ácido Fólico 130mg, Ácido Pantotênico 2.080,06mg, Niacina 5.600,10mg, Colina 57.274,69mg, veículo q.s.p 68,6269\%.

${ }^{2}$ Valores analisados ( Laboratório de Bromatologia da Universidade Federal do Tocantins).

As variáveis de desempenho avaliadas foram consumo de ração (CR), ganho de peso (GP) e conversão alimentar (CA).

Foram dispostas bandejas revestidas por lona plástica sob o piso de cada gaiola do $31^{\circ}$ ao $33^{\circ}$ dia de idade das aves para a coleta total de excretas (SIBBALD \& SLINGER, 1963; SIBBALD, 1976; MELO et al., 2009) conforme descrito por Sakomura \& Rostagno (2007). As coletas foram realizadas duas vezes ao dia (8 e 16h), para evitar fermentação, de acordo com Rodrigues et al. (2005). As excretas e as rações experimentais foram então acondicionadas em sacos plásticos, identificadas por repetição, congeladas e foram submetidas aos mesmos procedimentos laboratoriais do experimento 1. Foram realizadas análises de matéria seca (MS), extrato etéreo (EE), matéria mineral (MM), proteína bruta $(\mathrm{PB})$, energia bruta $(\mathrm{EB})$ e fibra em detergente neutro (FDN) (SILVA \& QUEIROZ, 2006).

Após as análises bromatológicas, foram determinados os coeficientes de metabolização da matéria seca (CMMS), extrato etéreo (CMEE), nitrogênio $(\mathrm{CMN})$, energia bruta (CMEB), fibra em detergente neutro (CMFDN), e os valores de energia metabolizável aparente corrigida (EMAn) das rações.

Para os cálculos dos coeficientes de metabolização dos nutrientes, utilizouse a seguinte fórmula:

$$
\mathrm{CM}(\%)=\frac{\mathrm{g} \text { de nutriente ingerido }-\mathrm{g} \text { de nutriente excretado }}{\mathrm{g} \text { de nutriente ingerido }} \times 100
$$


Rev. Bras. Saúde Prod. Anim., Salvador, v.15, n.2, p.470-483 abr./jun., 2014 http://www.rbspa.ufba.br ISSN 15199940

Os valores de energia metabolizável aparente corrigida (EMAn) foram determinados segundo a expressão descrita por Matterson et al. (1965):

$$
\text { EMAn da ração }(\mathrm{kcal} / \mathrm{kg})=\frac{\text { EBing._(EBexc._8,22xBN })}{\mathrm{MS}_{\text {ing. }}}
$$

Em que: $E M A n=$ energia metabolizável aparente corrigida ( $\mathrm{kcal} / \mathrm{kg}) ; \quad \mathrm{EB}$ ingerida $=$ energia bruta ingerida $(\mathrm{kcal})$; EB excretada = energia bruta excretada (kcal); $\mathrm{BN}=$ balanço de nitrogênio ((MS ingerida $\mathrm{x} \mathrm{N}$ da dieta) - (MS excretada $\mathrm{x} \mathrm{N}$ excretas)) e MS ingerida $=$ matéria seca ingerida $(\mathrm{kg})$.

As variáveis avaliadas foram submetidas a análises de variância segundo o modelo estatístico:

$Y_{i j}=\mu+R B D_{i}+e_{i j}$

Em que $Y_{i j}=$ valor observado para a variável dependente no i-ésimo nível de inclusão do resíduo de batata-doce; $\mu=$ efeito da média geral; $\mathrm{RBD}_{\mathrm{i}}=$ efeito do i-ésimo nível de inclusão do resíduo da batata-doce na ração, e $\mathrm{e}_{\mathrm{ij}}=$ erro experimental.

Posteriormente os dados foram submetidos a análises de regressão por meio de modelos polinomiais de primeira ou segunda ordem. Para o ajuste dos modelos foram considerados o nível de significância do teste $\mathrm{F}(5 \%)$ e o coeficiente de determinação da equação $\left(\mathrm{R}^{2}\right)$. Para as análises estatísticas utilizou-se o software SAS 9.0 por meio do procedimento GLM (General Linear Models) (STATISTICAL ANALYSIS SYSTEM, 1998).

\section{RESULTADOS E DISCUSSÃO}

Os valores encontrados do resíduo da batata-doce estão expressos na Tabela 4, e diferem dos apresentados por Silveira et al. (2008), em que a matéria seca foi de $88 \%$, a proteína bruta $14,52 \%$ e o extrato etéreo 2,92\% que foram inferiores aos encontrados no presente estudo. Rodrigues \& Rodrigues (2012) também avaliaram o resíduo da produção etanol a partir da batata-doce e encontraram valores diferentes do presente estudo, $17,66 \%$ de proteína bruta, $1,73 \%$ de extrato etéreo, $6,76 \%$ de matéria mineral e $36,85 \%$ de fibra em detergente neutro, classificando o alimento como concentrado e energético. Essas variações podem ser atribuídas ao fato de que a composição química e energética dos alimentos de origem vegetal pode ser influenciada por fatores como: solo, clima e variabilidade genética (Tabela 4). No caso de subprodutos, além desses fatores, o tipo e o tempo de processamento e as condições de armazenamento dos alimentos podem influenciar a composição (FREITAS et al., 2005; BRUMANO et al., 2006; GOMES et al., 2007; NERY et al., 2007).

Tabela 4. Composição bromatológica do resíduo da batata-doce ${ }^{1}$

\begin{tabular}{lc}
\hline Item & $\begin{array}{c}\text { Resíduo da } \\
\text { batata-doce }\end{array}$ \\
\hline Matéria seca (\%) & 92,75 \\
Proteína bruta (\%) & 24,64 \\
Energia bruta (kcal/kg) & 4499 \\
Fibra em detergente neutro (\%) & 47,41 \\
Extrato etéreo (\%) & 5,25 \\
Matéria Mineral (\%) & 8,41 \\
\hline${ }^{1}$ Valores expressos com base na matéria natural.
\end{tabular}

${ }^{1}$ Valores expressos com base na matéria natural. 
Rostagno et al. (2005) apresenta valores de matéria seca de $88,72 \%$, proteína bruta de $3,87 \%$, extrato etéreo $0,91 \%$, matéria mineral de $3,00 \%$ e energia bruta de $3875 \mathrm{kcal} / \mathrm{kg}$ para a farinha de batata-doce integral, todos inferiores ao resíduo de batata-doce utilizado no presente estudo.

Essa diferença entre a farinha integral e o resíduo da batata-doce, deve-se ao processamento que a batata-doce sofre para geração do álcool, que passa por vários processos como cozimento, hidrólise do amido, sacarificação, adição de fungos, fermentação, resfriamento e destilação, modificando as características originais do produto.

A variabilidade de valores encontrados demonstra que alimentos alternativos variam constantemente os seus teores de nutrientes, isso ocorre devido à falta de padronização para obtenção do produto. Isso demonstra a importância das análises locais para a adequação das tabelas de composição bromatológica de alimentos alternativos.
A partir da pesquisa envolvendo a produção do álcool de batata-doce desenvolvida por Silveira et al. (2008), foi que se iniciaram estudos visando o aproveitamento da significativa quantidade do resíduo gerado nesse processo. Atualmente pode-se sugestionar a elaboração de diversas composições de rações para alimento animal. Os testes preliminares indicaram que esse resíduo encerra propriedades nutricionais que sustentam essa utilização, o que pode vir a constituir uma fonte de renda valiosa para o produtor que, frente ao usineiro, poderia negociar o retorno do resíduo a sua propriedade para o uso na produção animal.

O valor de energia metabolizável aparente de $2732 \mathrm{kcal} / \mathrm{kg}$ determinado no presente estudo foi semelhante ao valor $2706 \mathrm{kcal} / \mathrm{kg}$ de EMAn apresentado por Rostagno et. al. (2011) para a farinha da batata-doce. Isso demonstra que apesar do processamento, a disponibilidade de energia da batata-doce permanece inalterada (Tabela 5).

Tabela 5. Médias ( \pm erros padrão) de energia metabolizável aparente (EMA) e energia metabolizável aparente corrigida (EMAn), e coeficientes de metabolização aparente da matéria seca (CMAMS), proteína bruta (CMAPB), extrato etéreo (CMAEE) e energia bruta (CMAEB) do resíduo da batata-doce

\begin{tabular}{lc}
\hline Energia $^{1}$ & Valor energético \\
\hline $\begin{array}{l}\text { Energia metabolizável aparente }(\mathrm{kcal} / \mathrm{kg}) \\
\text { Energia metabolizável aparente corrigida }(\mathrm{kcal} / \mathrm{kg})\end{array}$ & $2732 \pm 163$ \\
\multicolumn{2}{c}{ Coeficientes de metabolização } \\
\hline Matéria seca (\%) & $2547 \pm 150$ \\
Proteína bruta (\%) & $63,30 \pm 2,49$ \\
Extrato etéreo (\%) & $54,46 \pm 3,70$ \\
Energia bruta (\%) & $28,74 \pm 4,59$ \\
\hline
\end{tabular}

${ }^{1}$ Valores expressos na matéria natural.

O tratamento térmico pode proporcionar reações de complexação entre os nutrientes, que pode torná-los indigeríveis e reduzir sua absorção, afetando a metabolização da energia bruta do alimento. As magnitudes destes efeitos variam conforme a metodologia do processamento empregado pelas empresas. (ALBINO et al., 1986). 


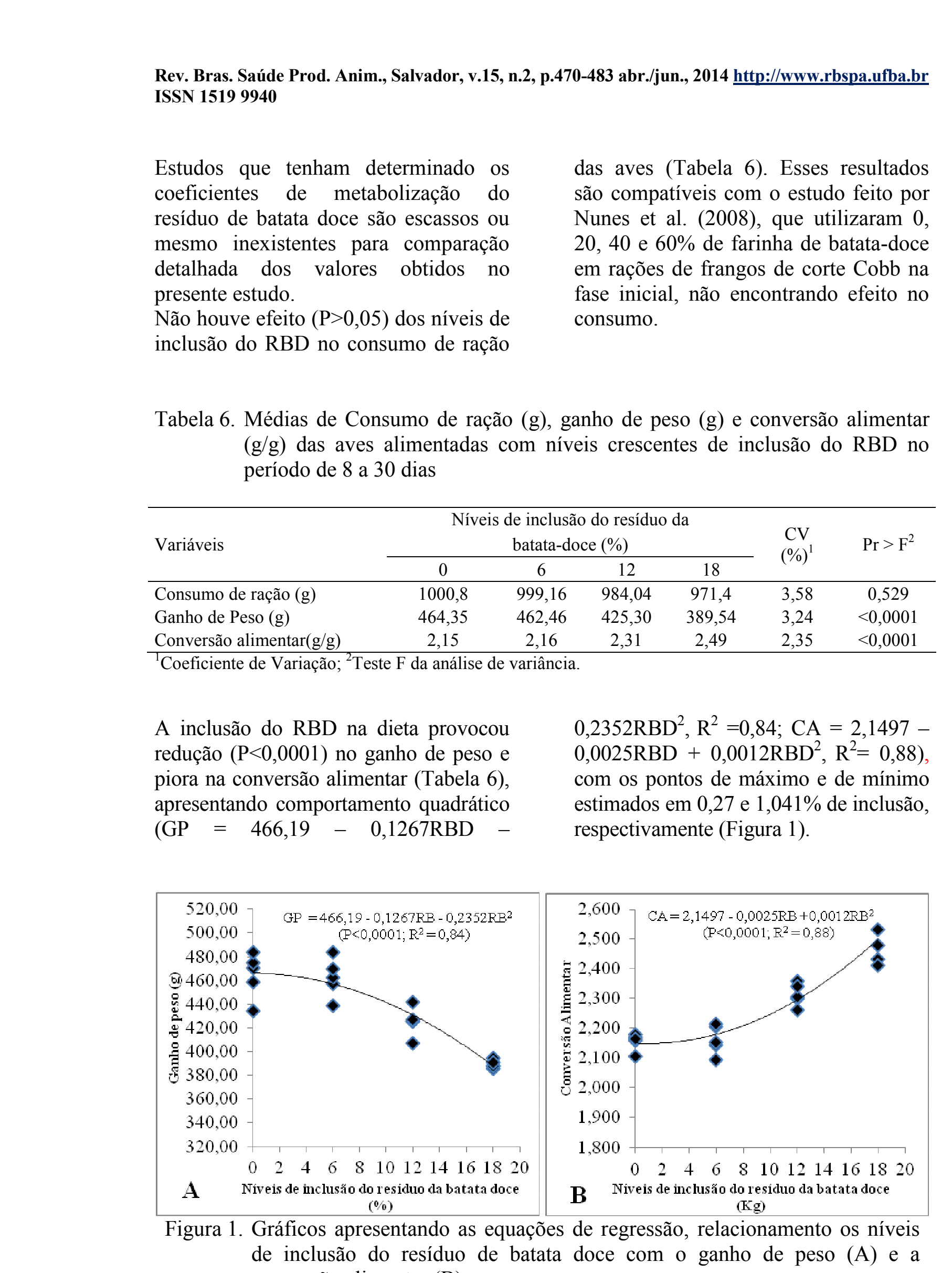

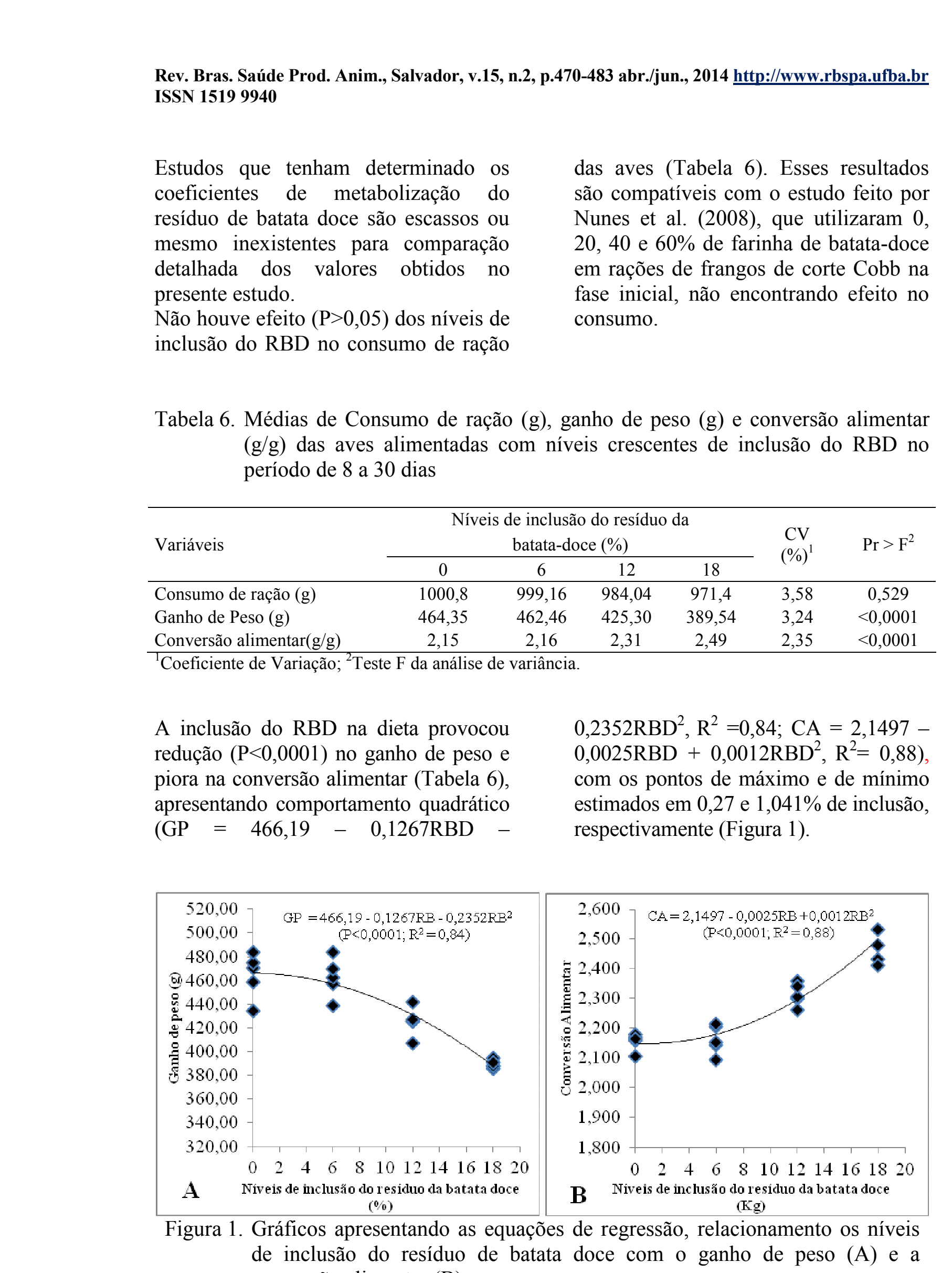

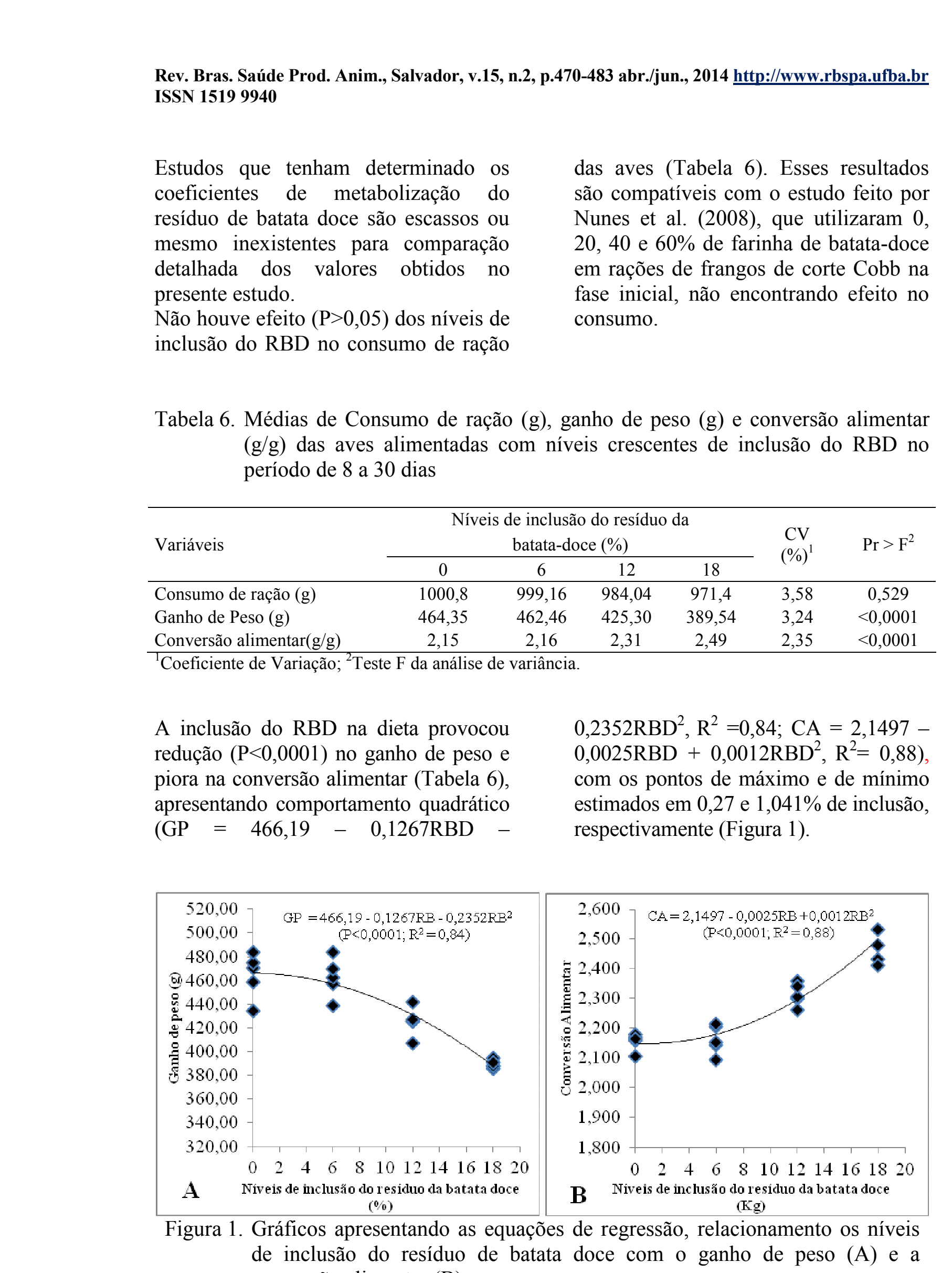

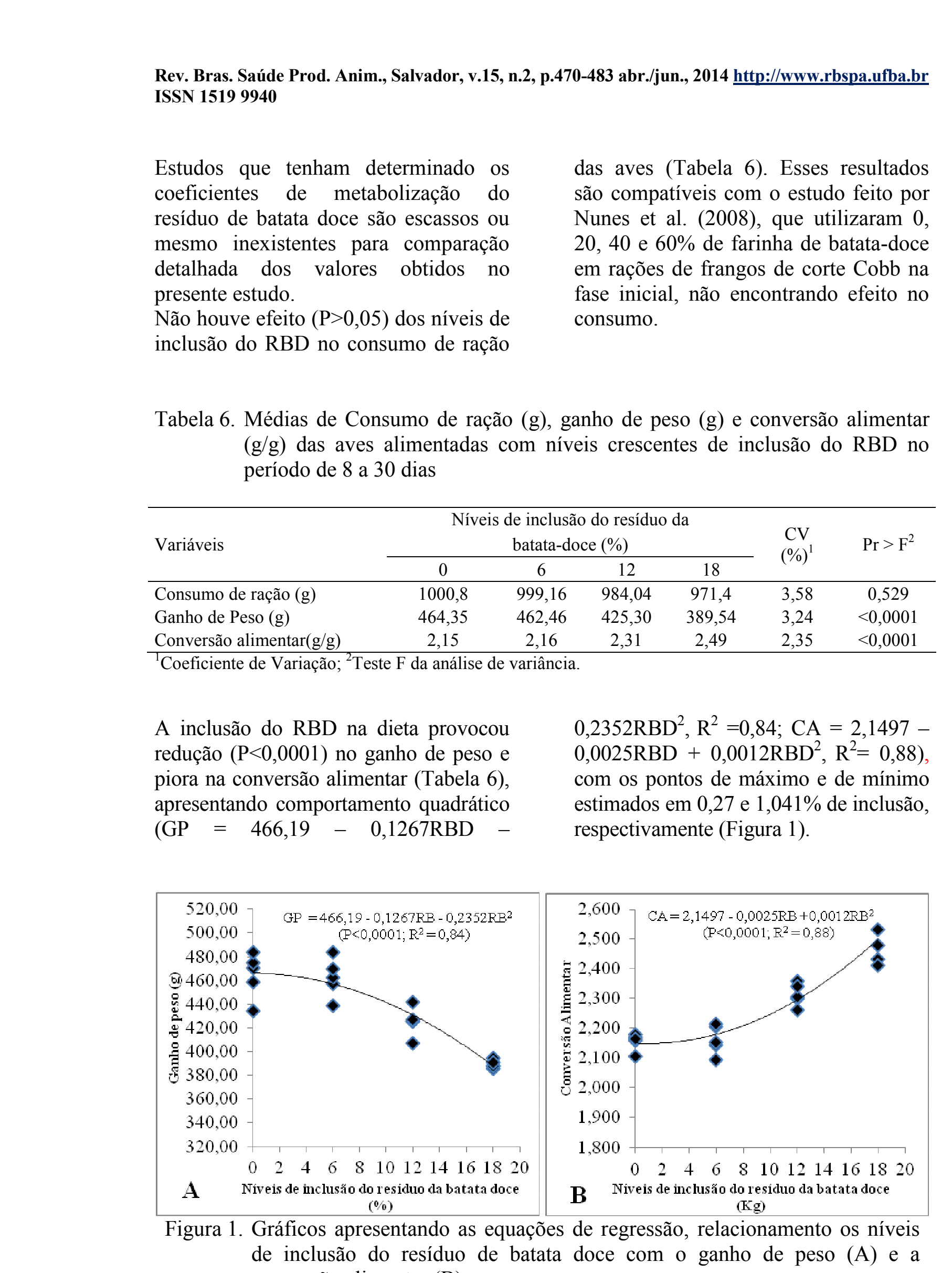

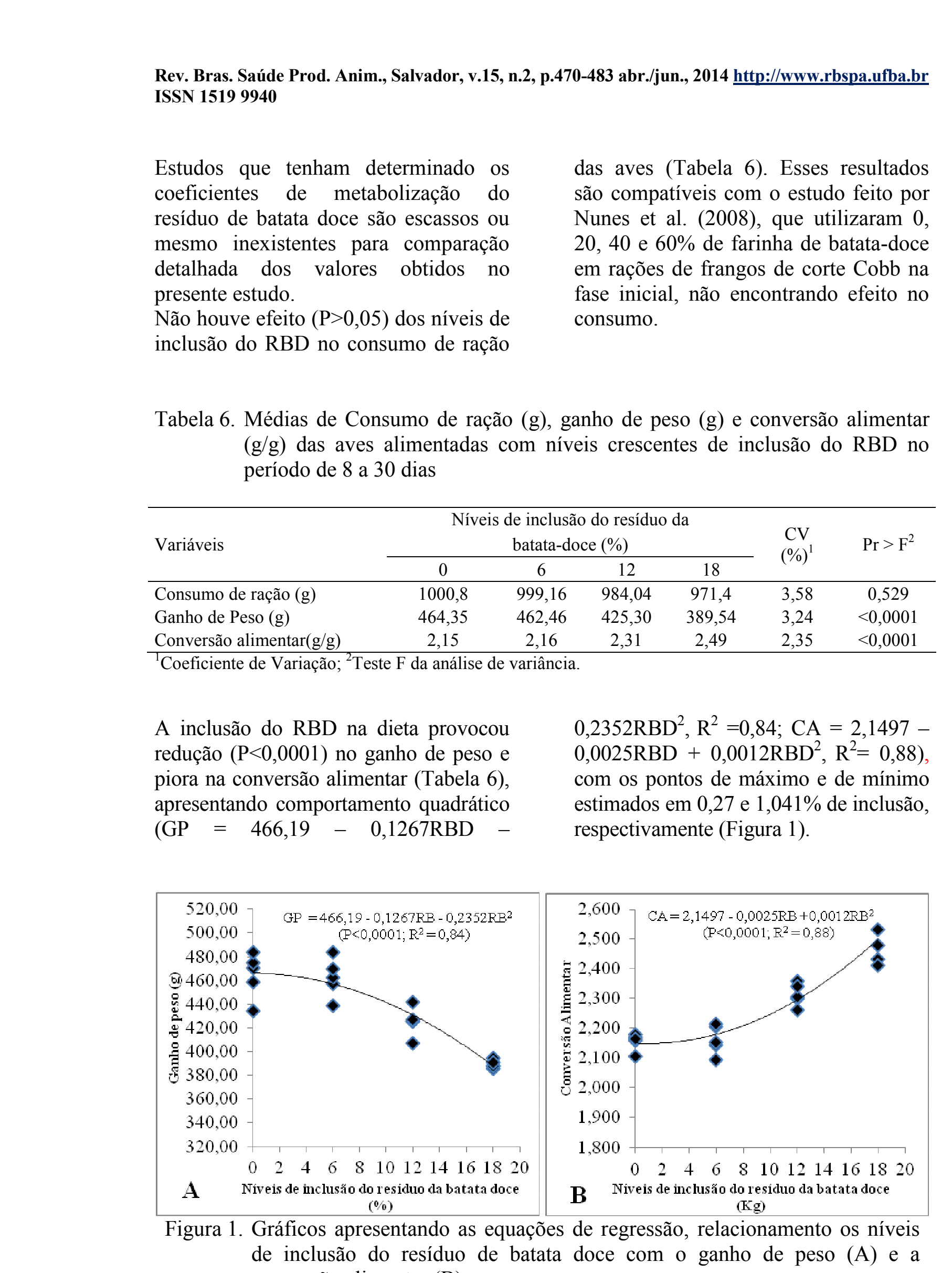

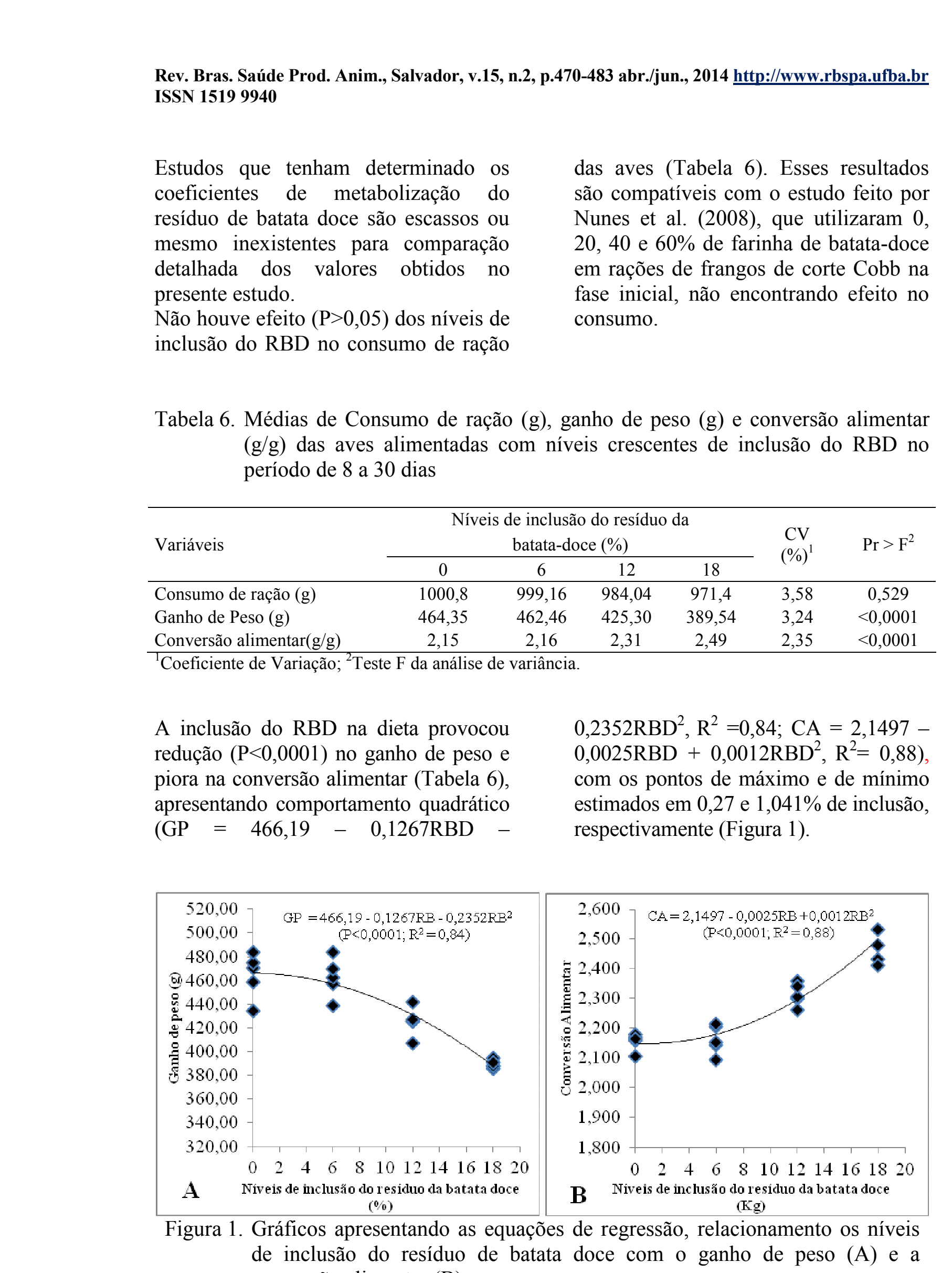

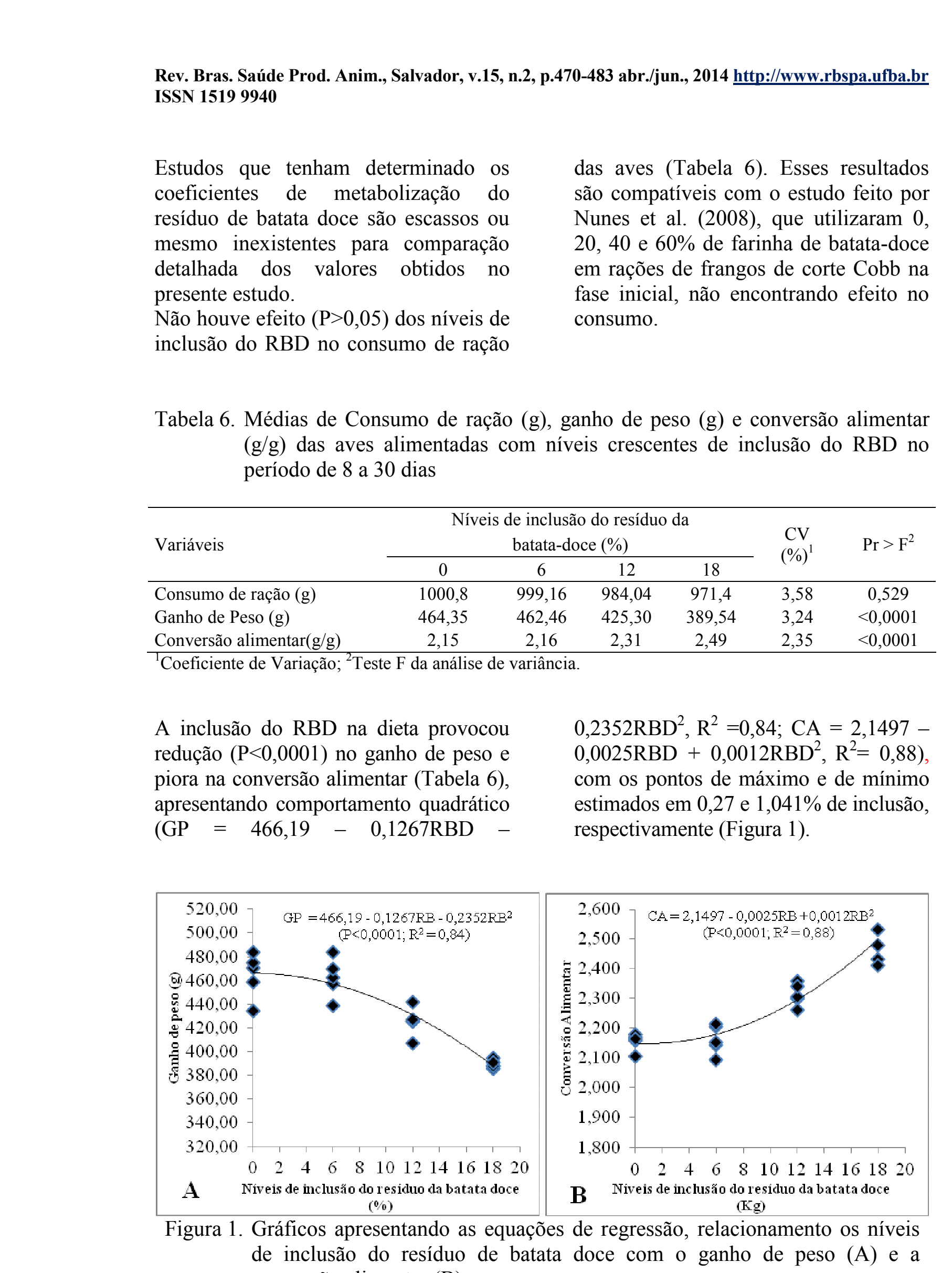

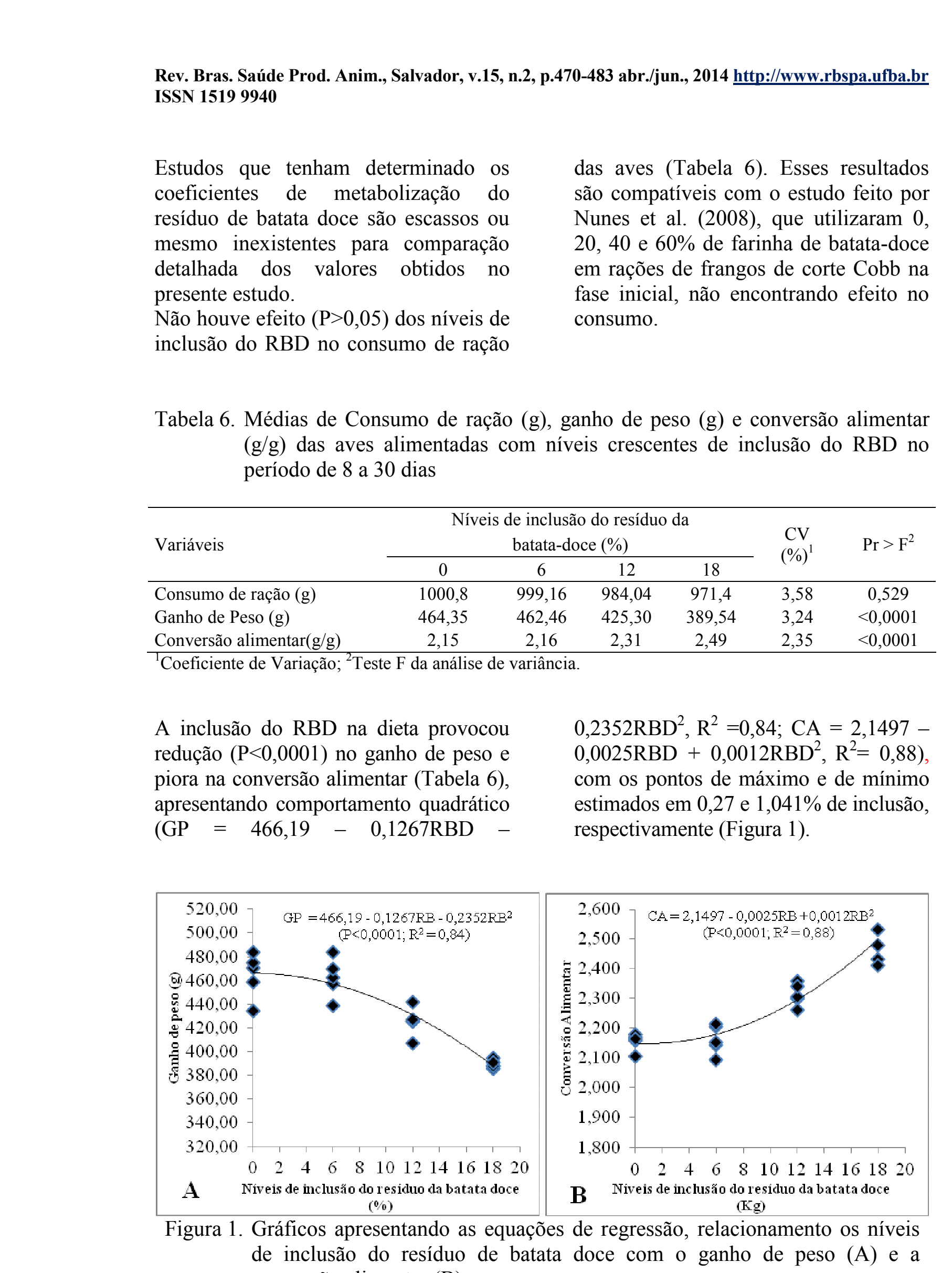

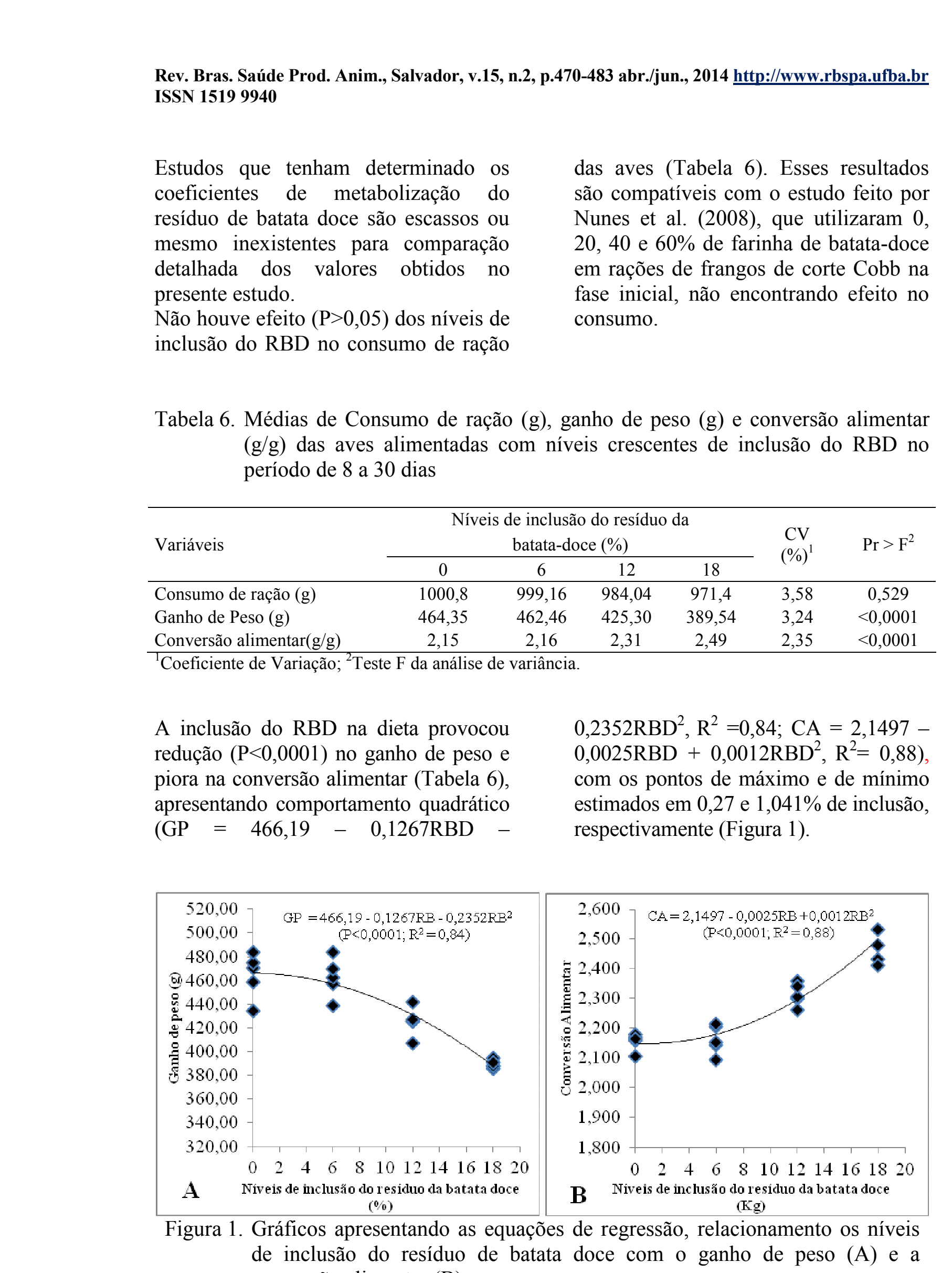

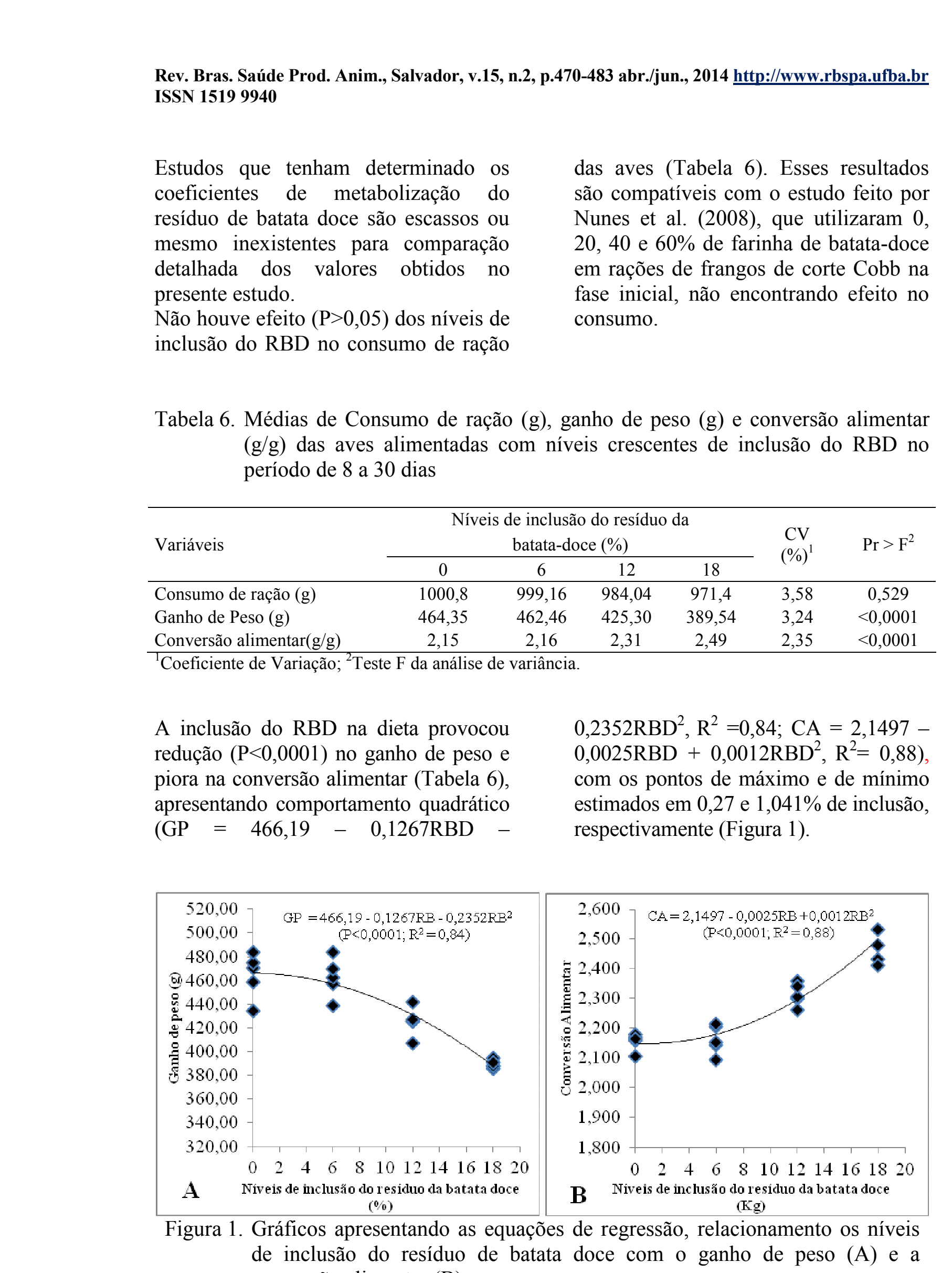

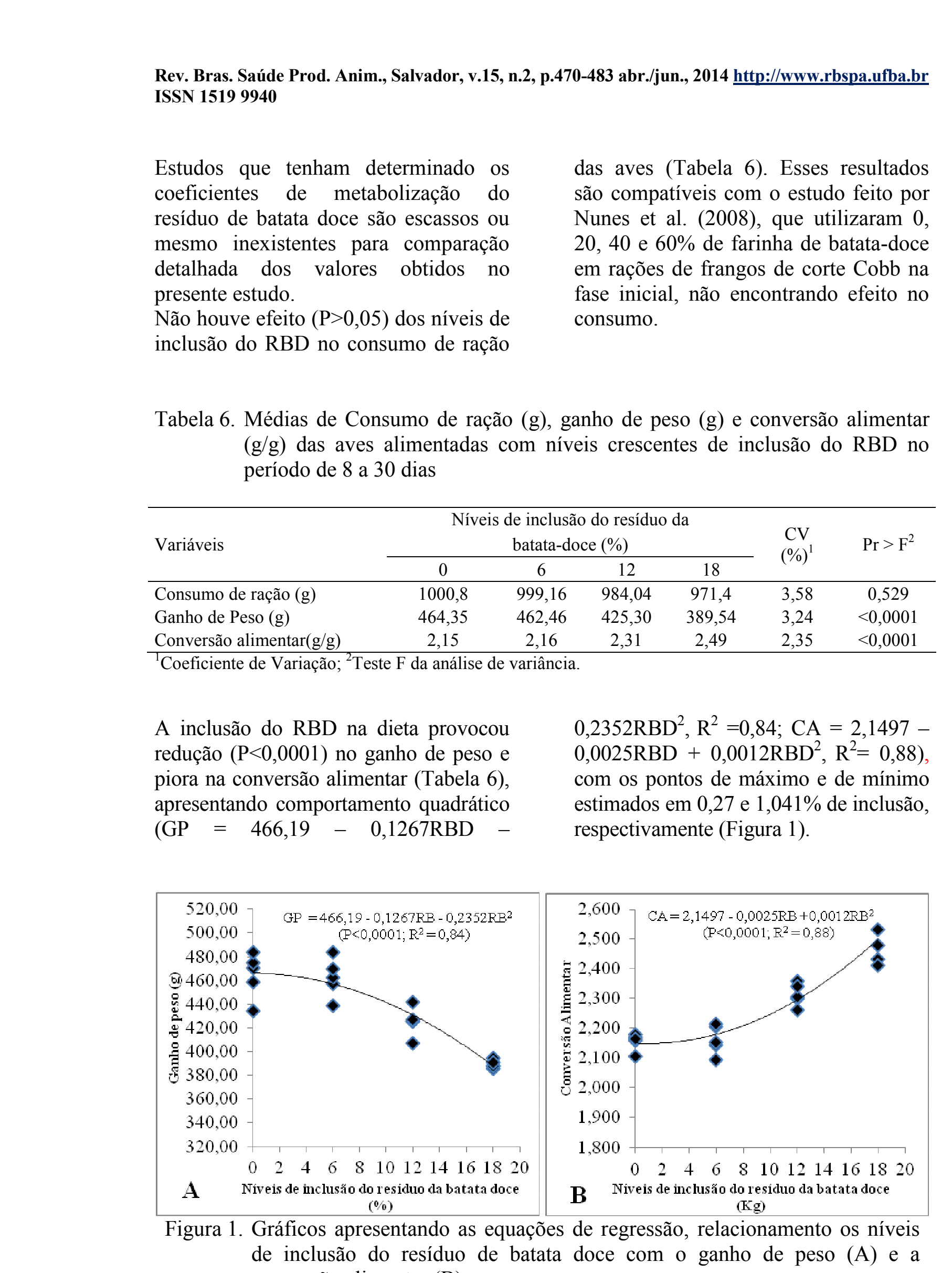

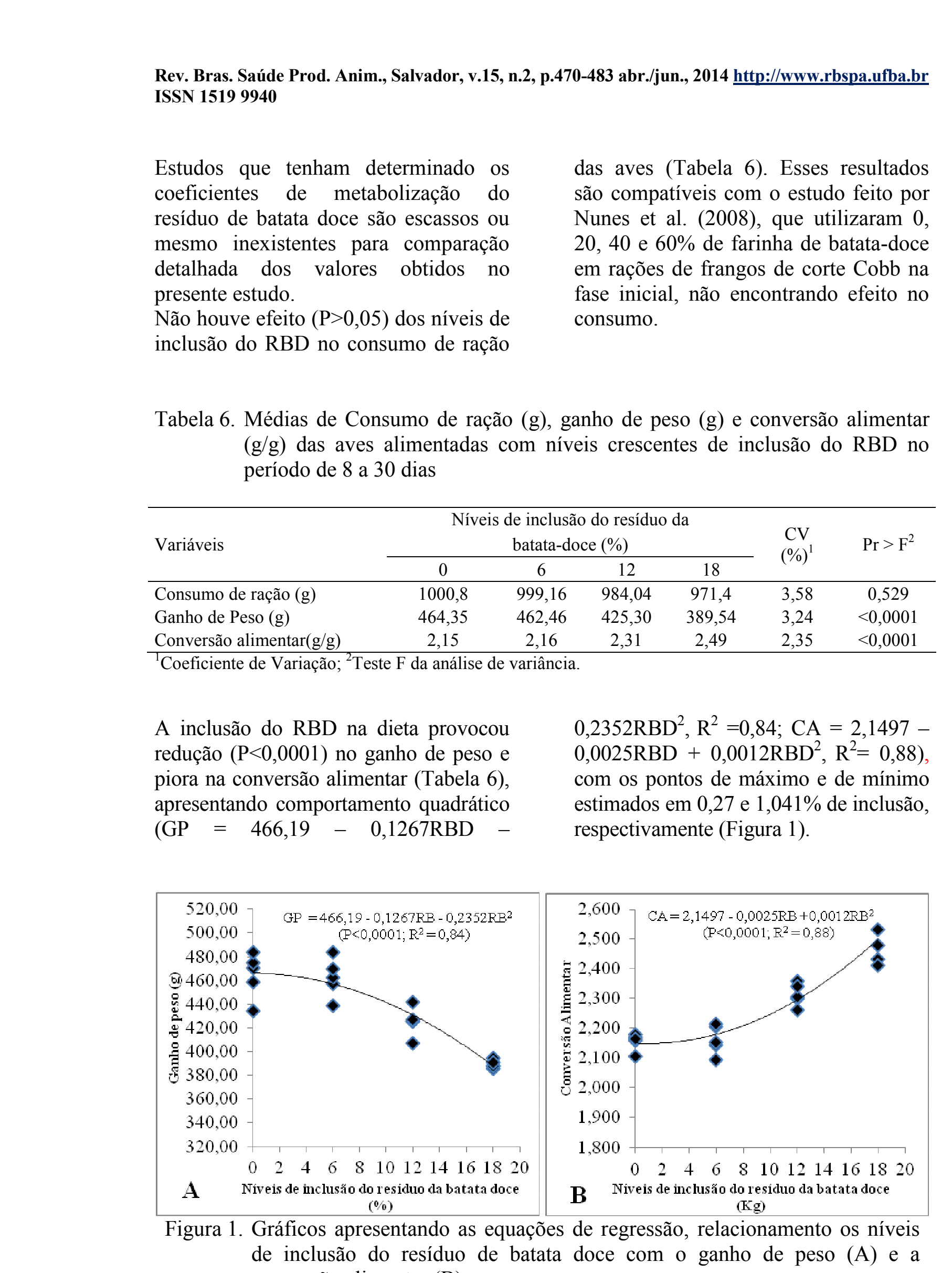

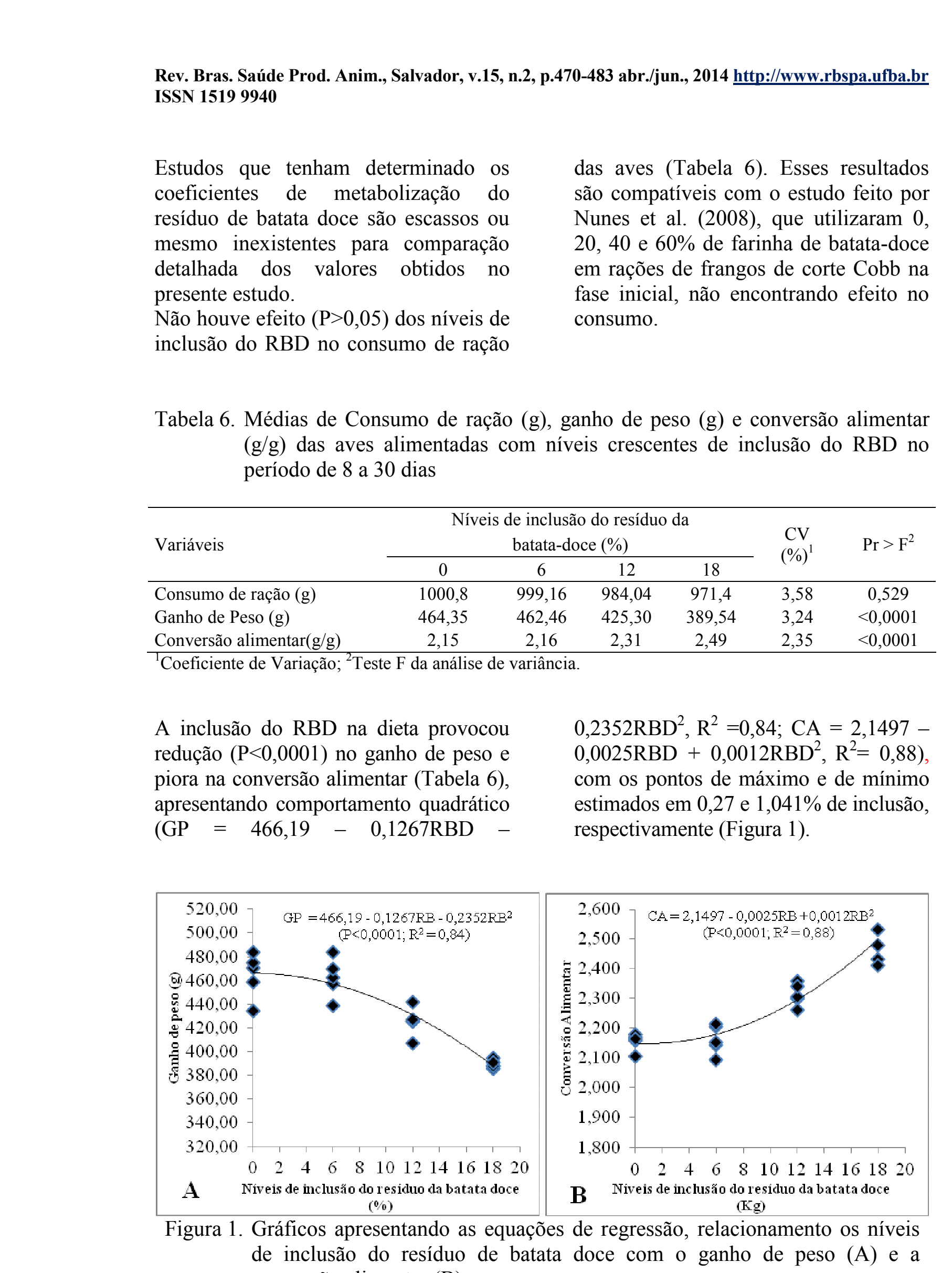

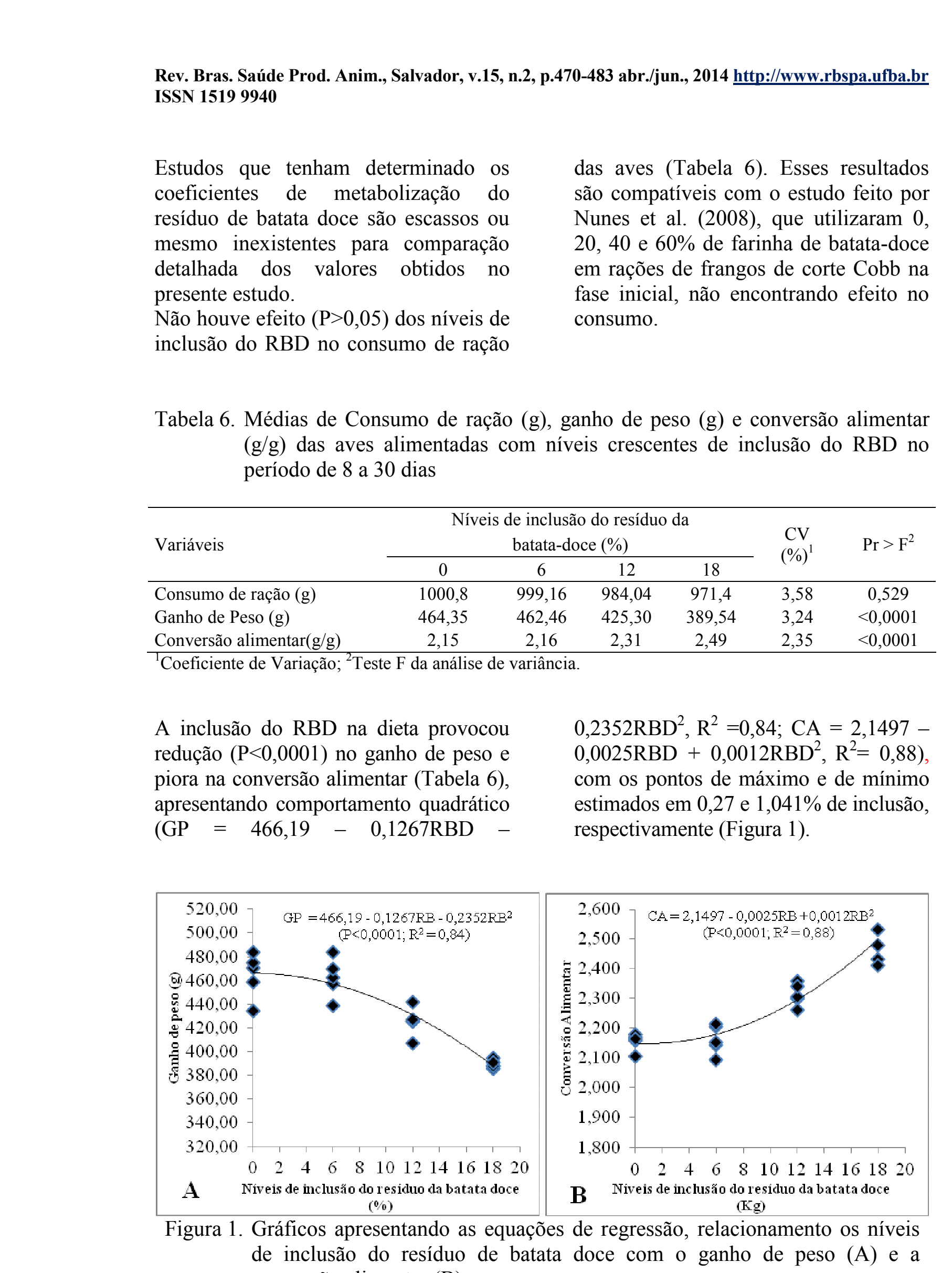

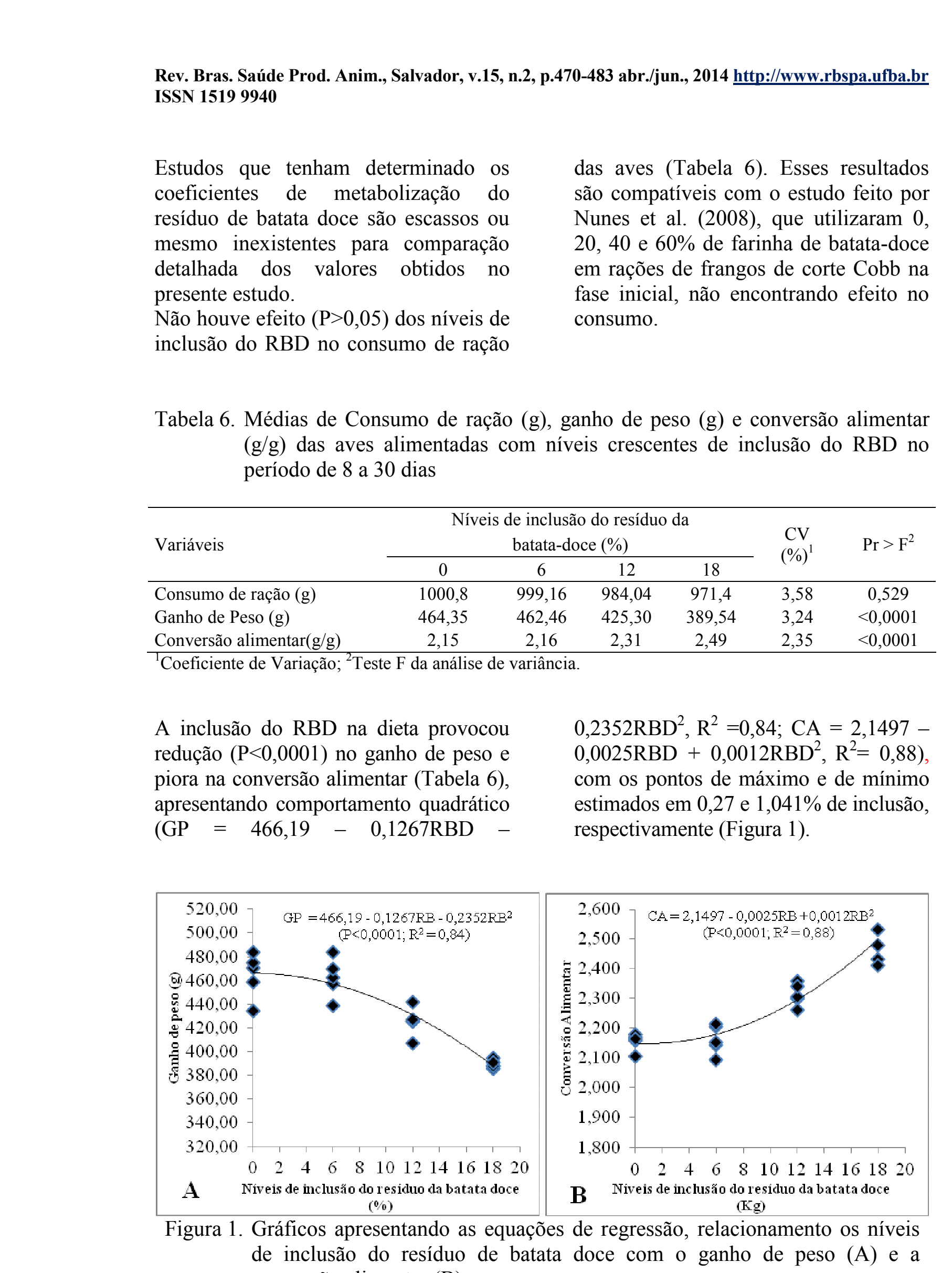

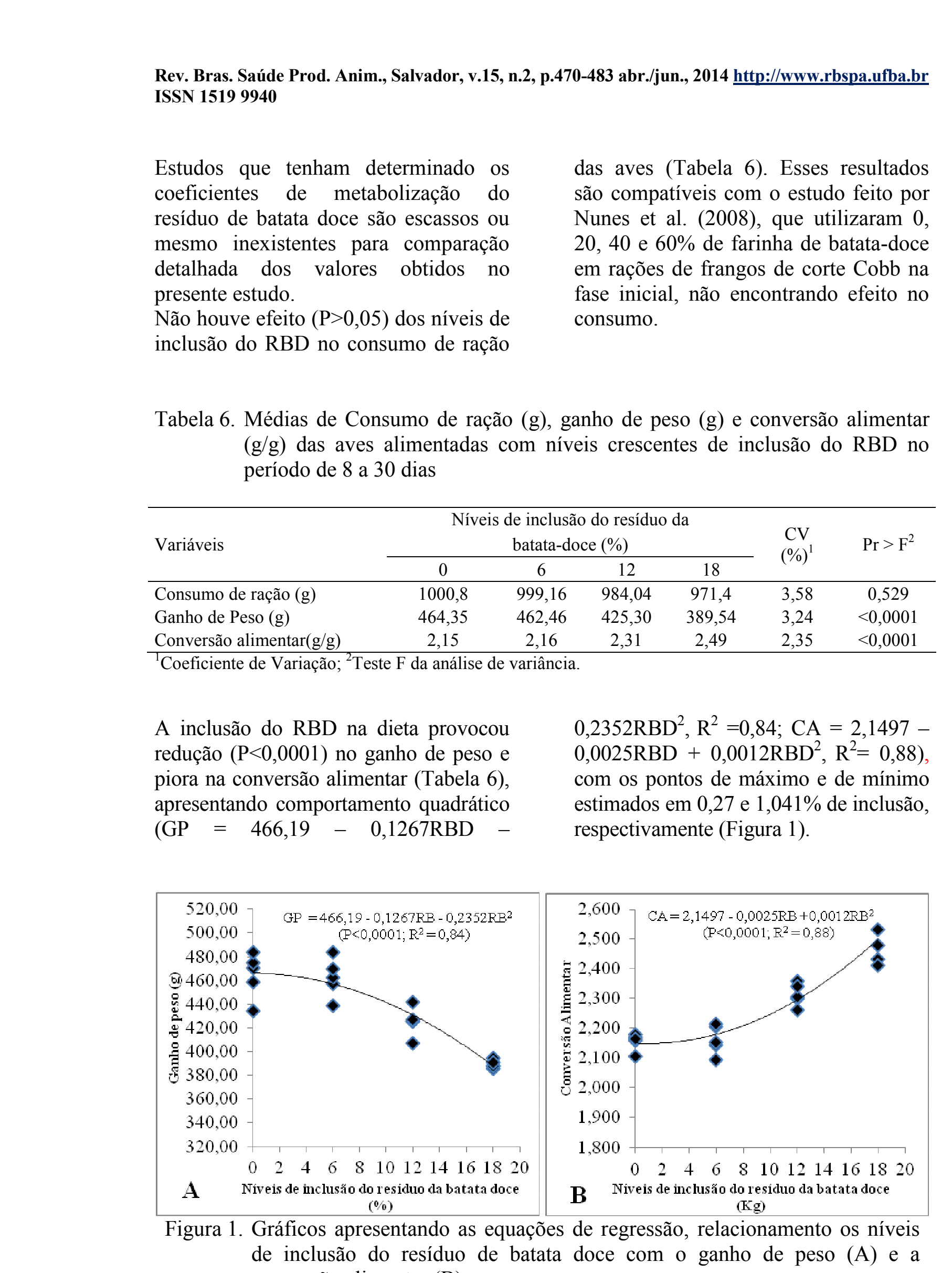

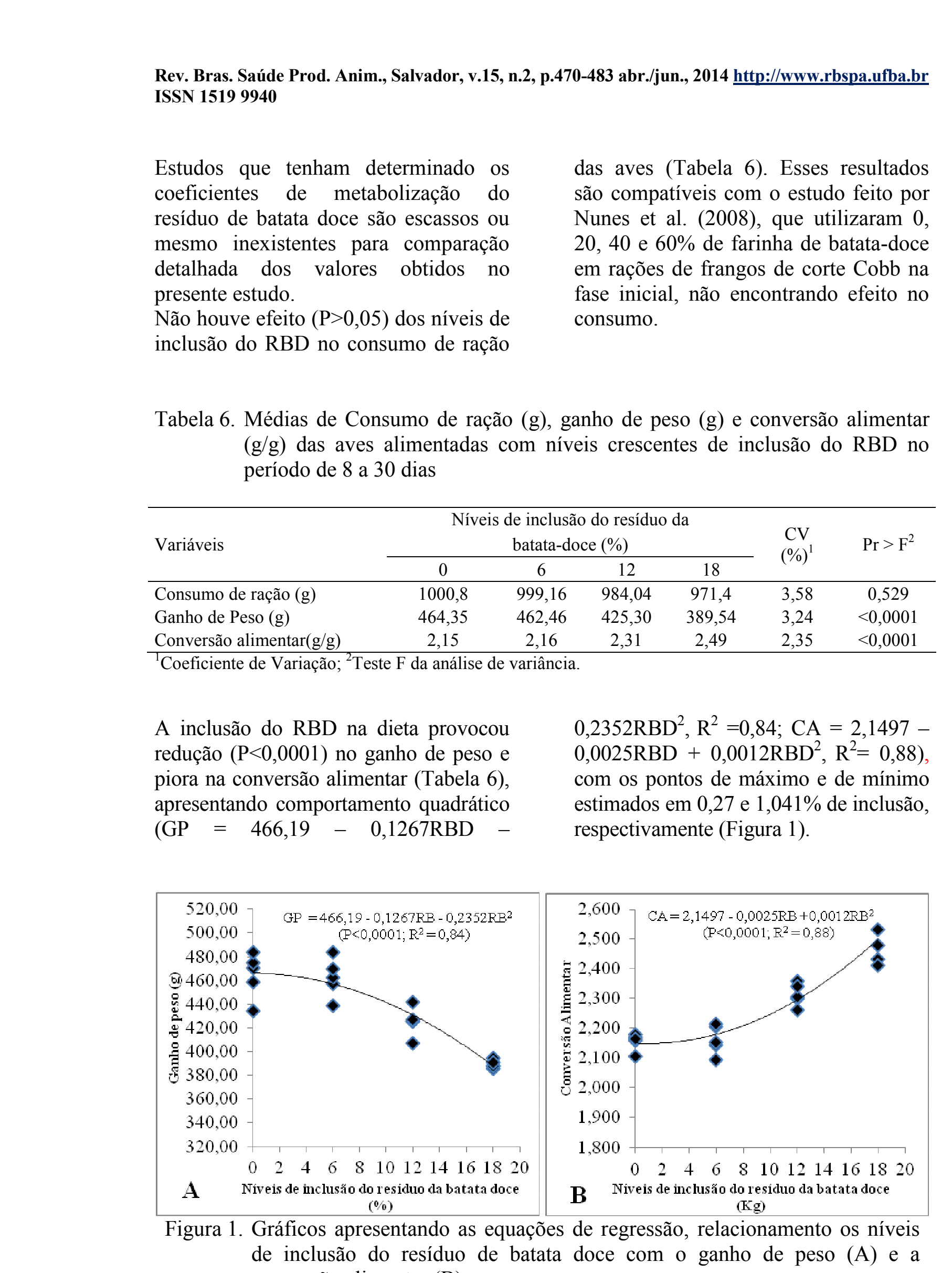

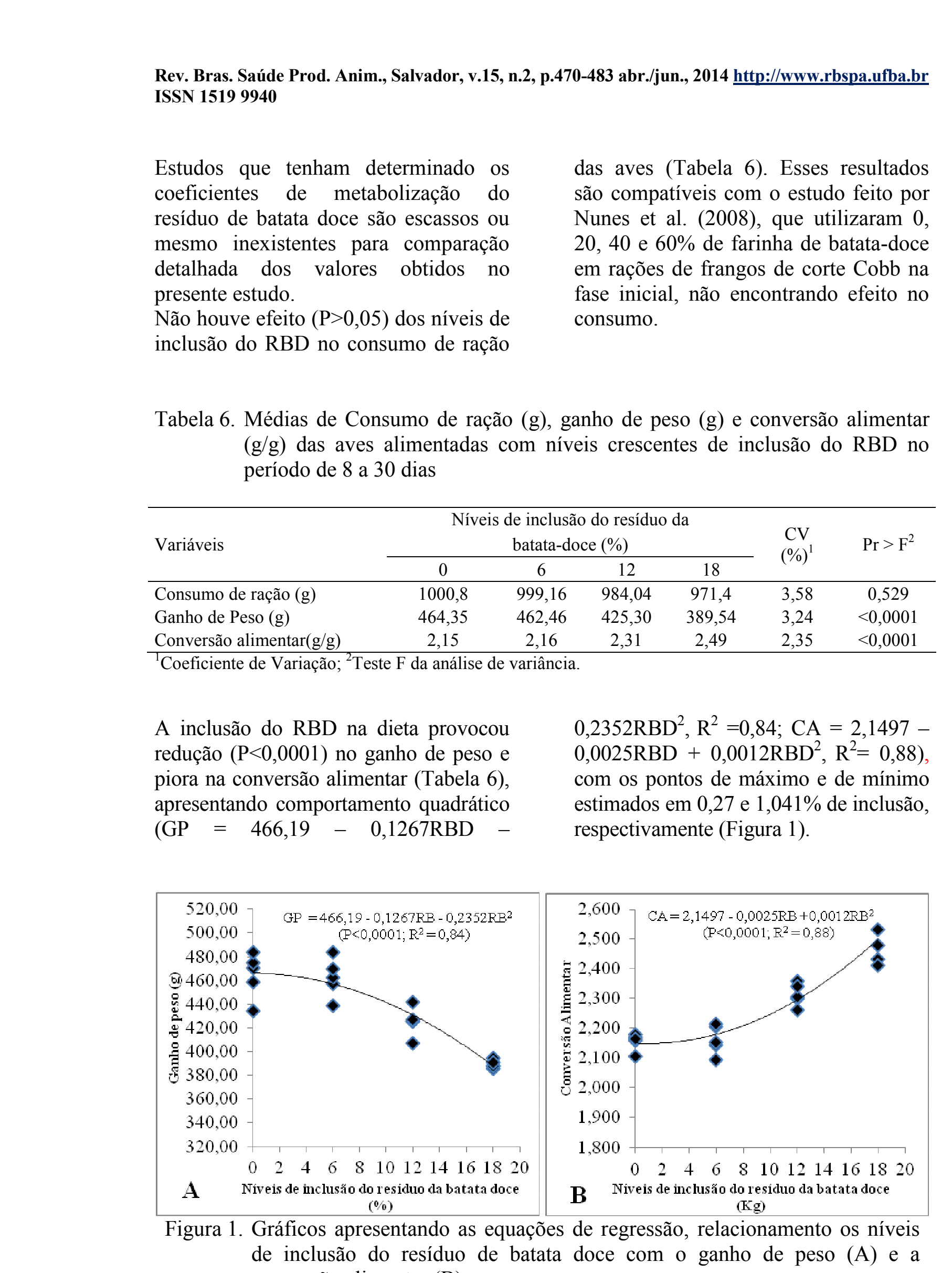

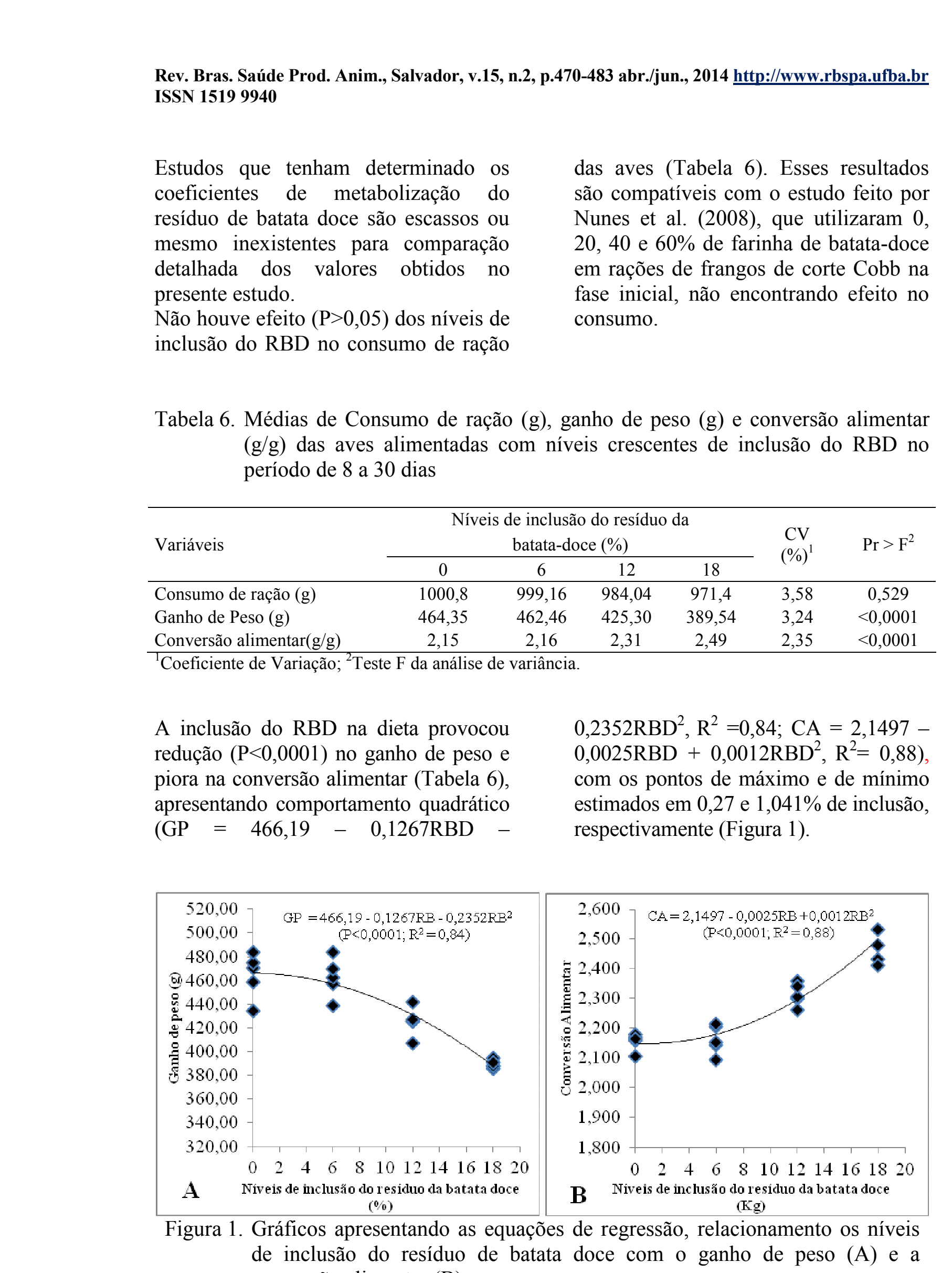

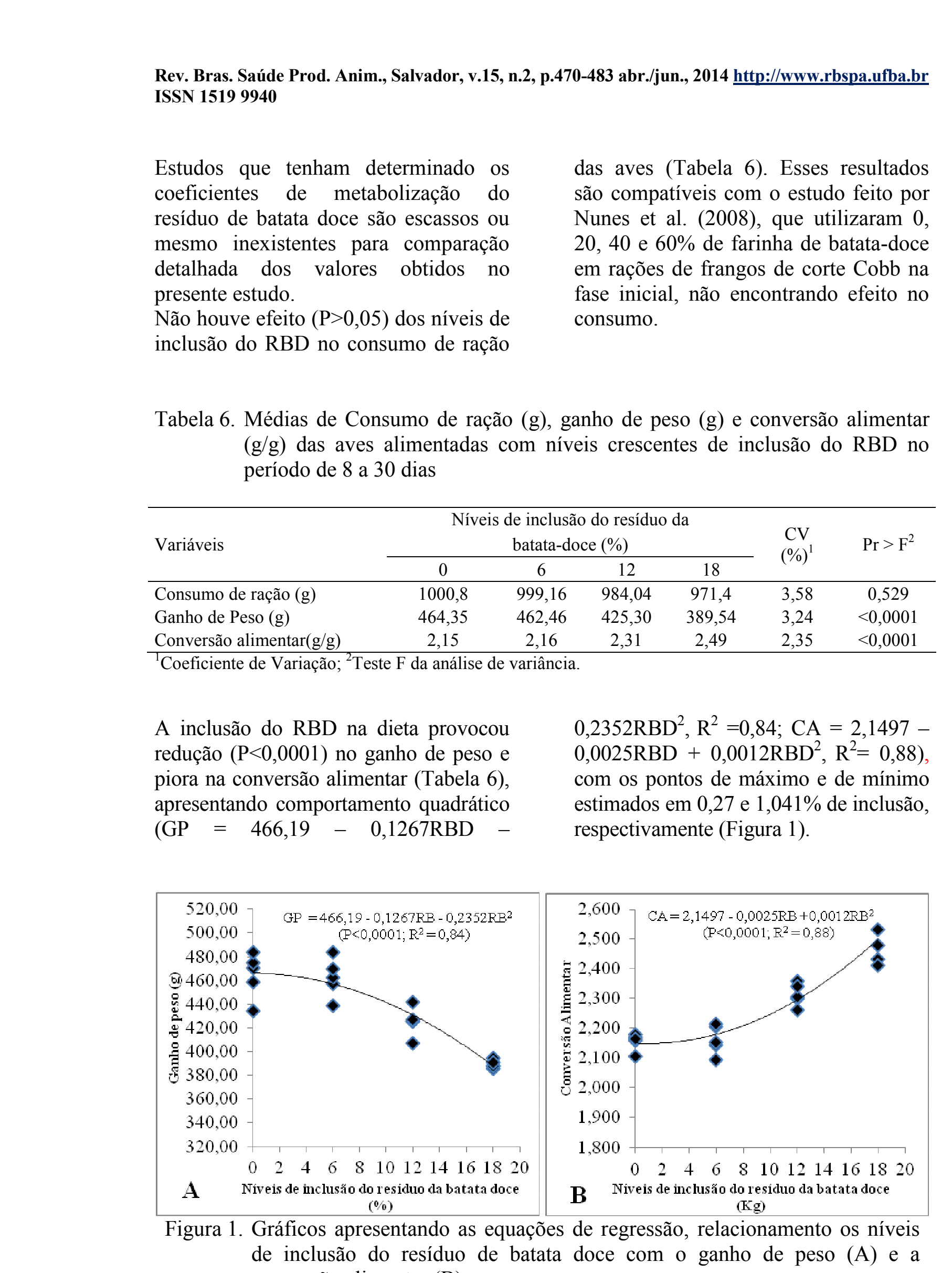

\begin{tabular}{|c|c|c|c|c|c|c|}
\hline \multirow[t]{2}{*}{ Variáveis } & \multicolumn{4}{|c|}{$\begin{array}{l}\text { Níveis de inclusão do resíduo da } \\
\text { batata-doce }(\%)\end{array}$} & \multirow{2}{*}{$\begin{array}{l}\mathrm{CV} \\
(\%)^{1}\end{array}$} & \multirow[t]{2}{*}{$\operatorname{Pr}>F^{2}$} \\
\hline & 0 & 6 & 12 & 18 & & \\
\hline Consumo de ração (g) & 1000,8 & 999,16 & 984,04 & 971,4 & 3,58 & 0,529 \\
\hline Ganho de Peso (g) & 464,35 & 462,46 & 425,30 & 389,54 & 3,24 & $<0,0001$ \\
\hline Conversão alimentar(g/g) & 2,15 & 2,16 & 2,31 & 2,49 & 2,35 & $<0,0001$ \\
\hline
\end{tabular}

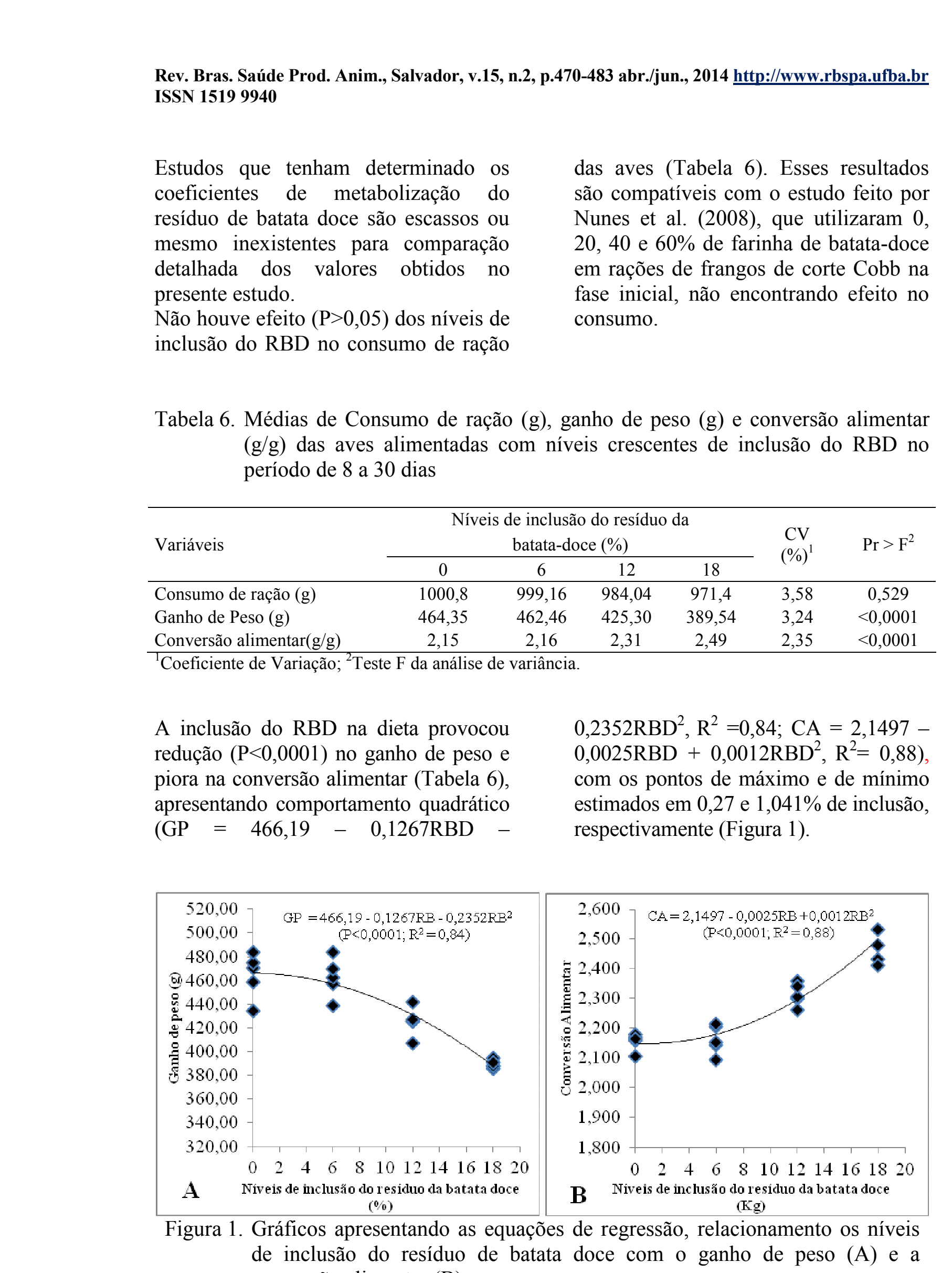

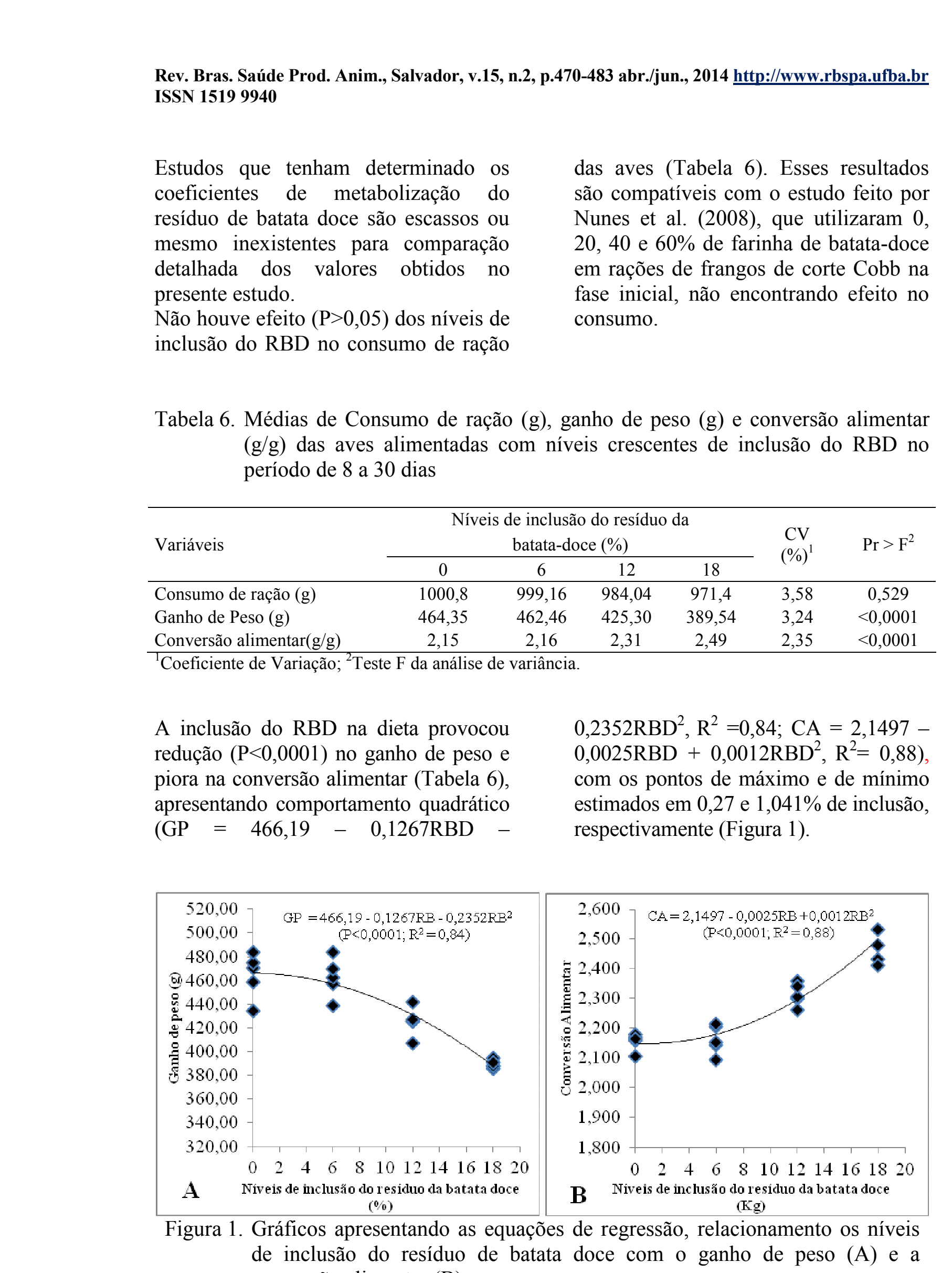

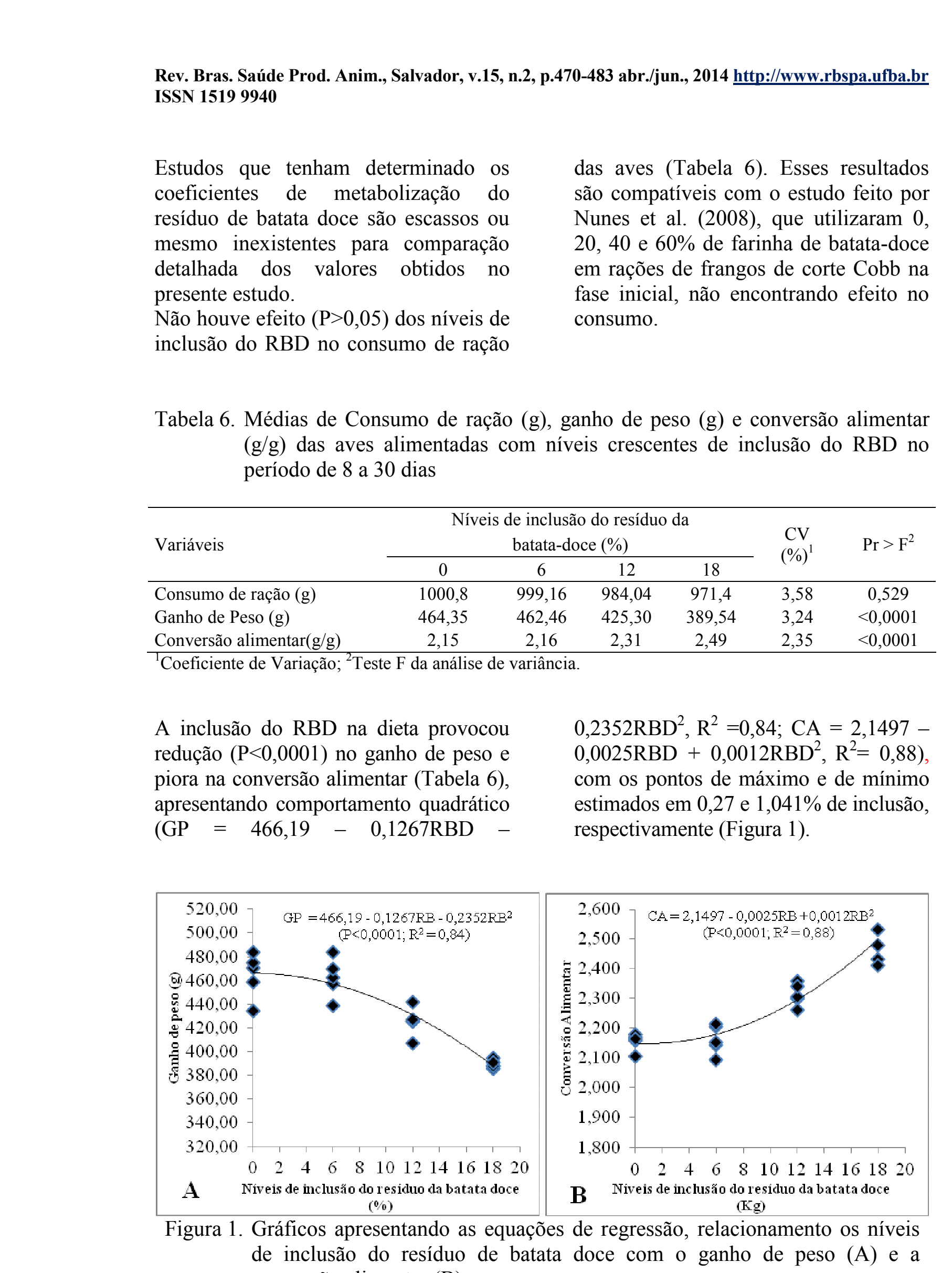

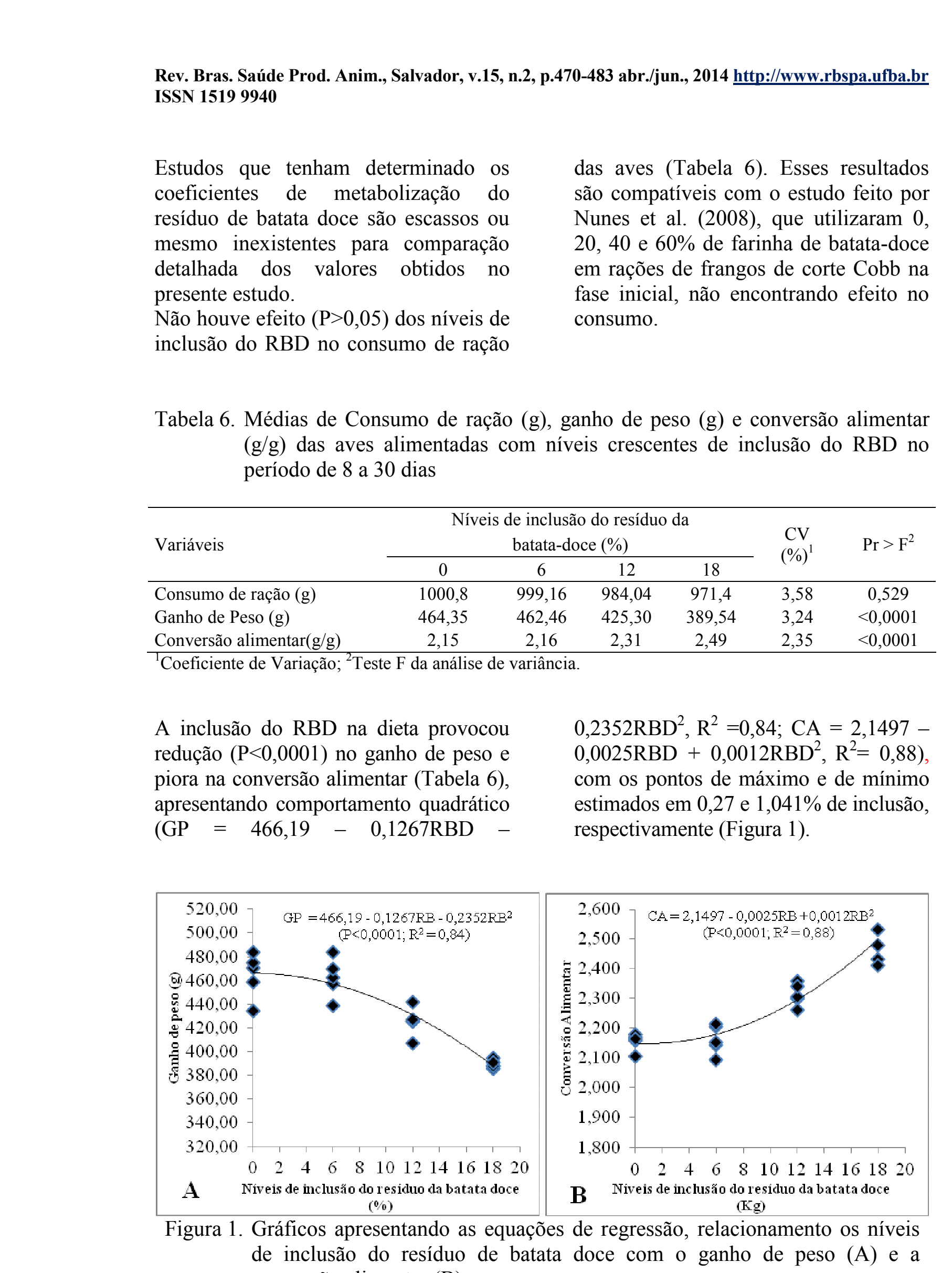

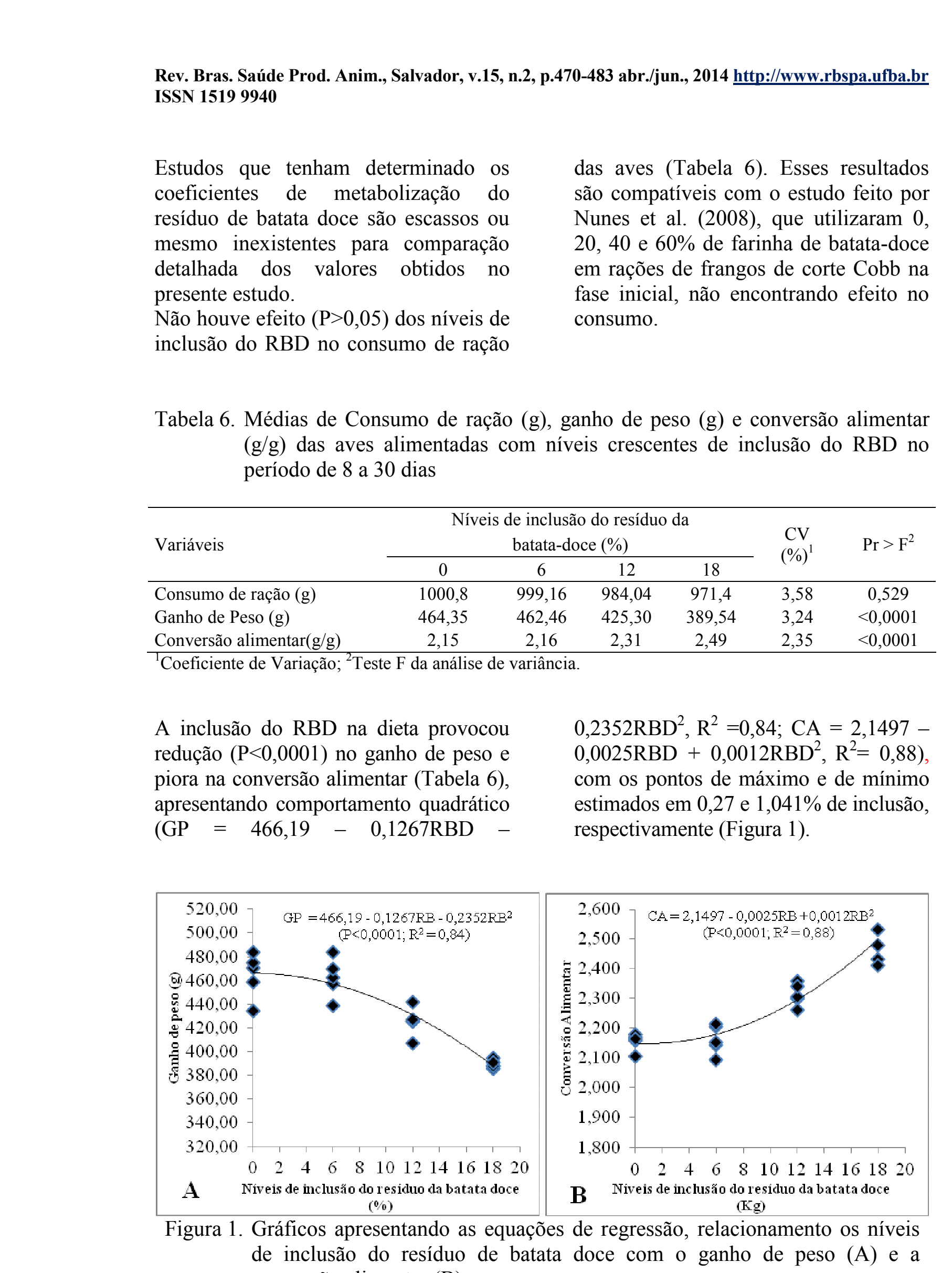

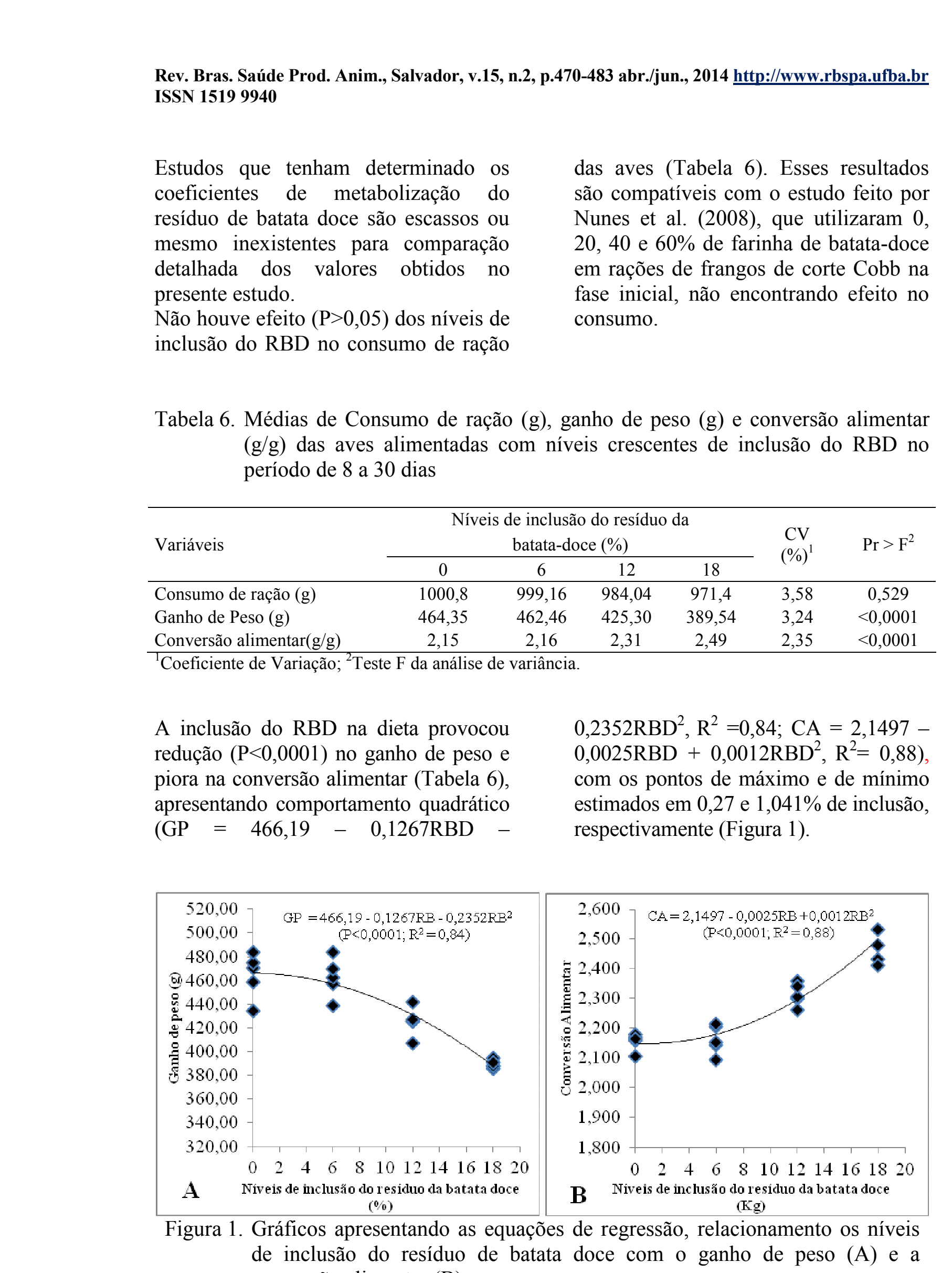

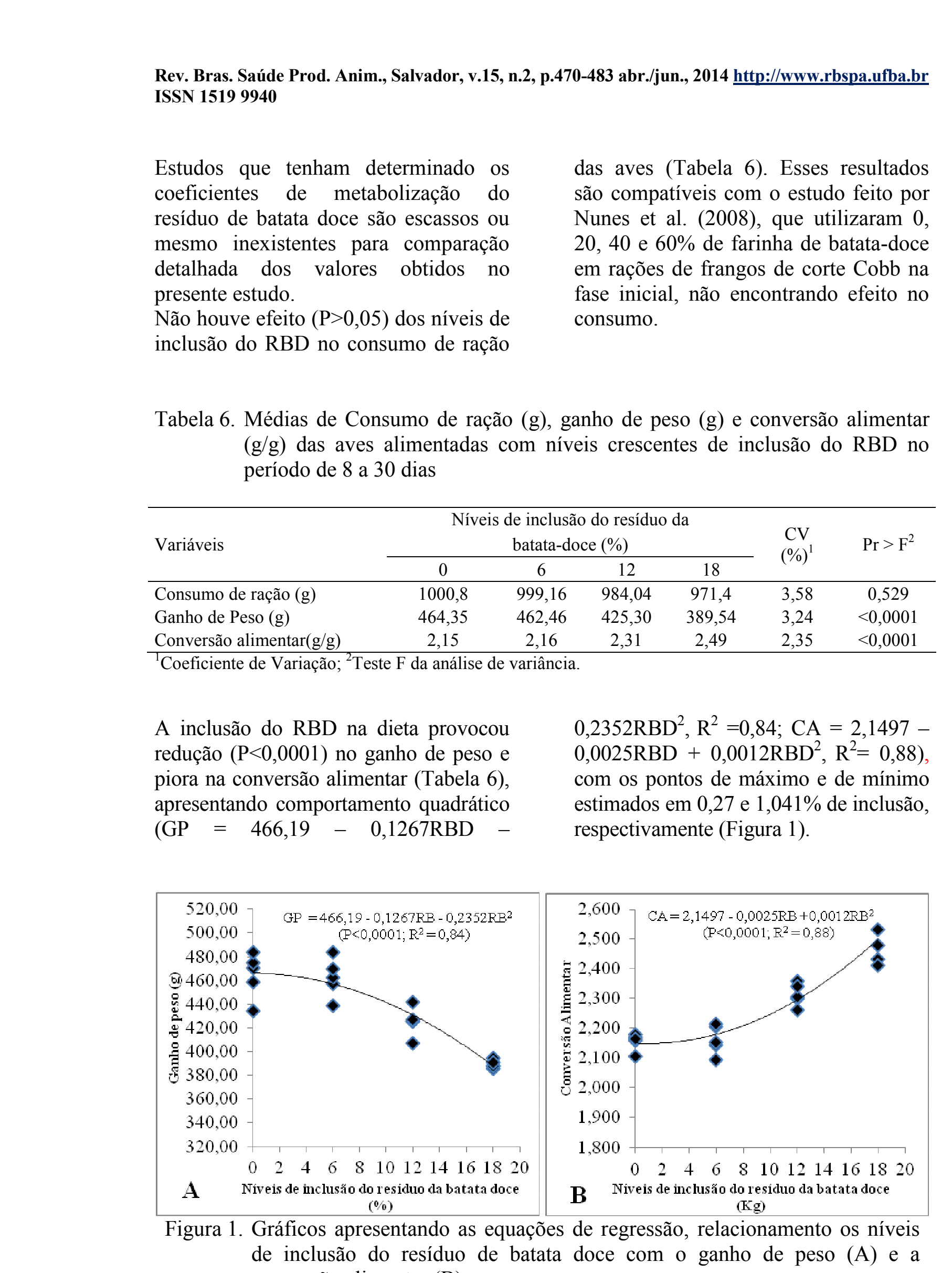

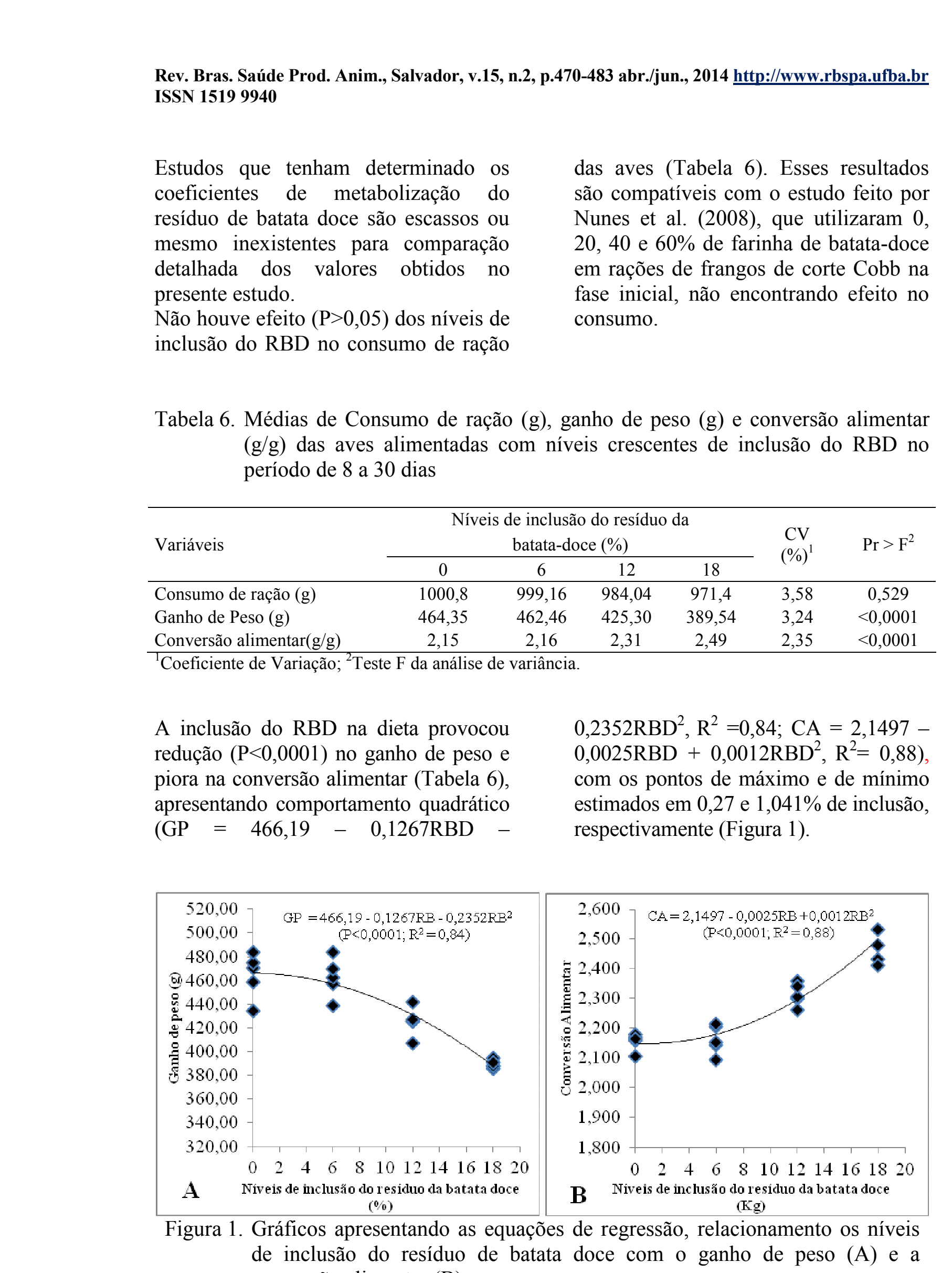

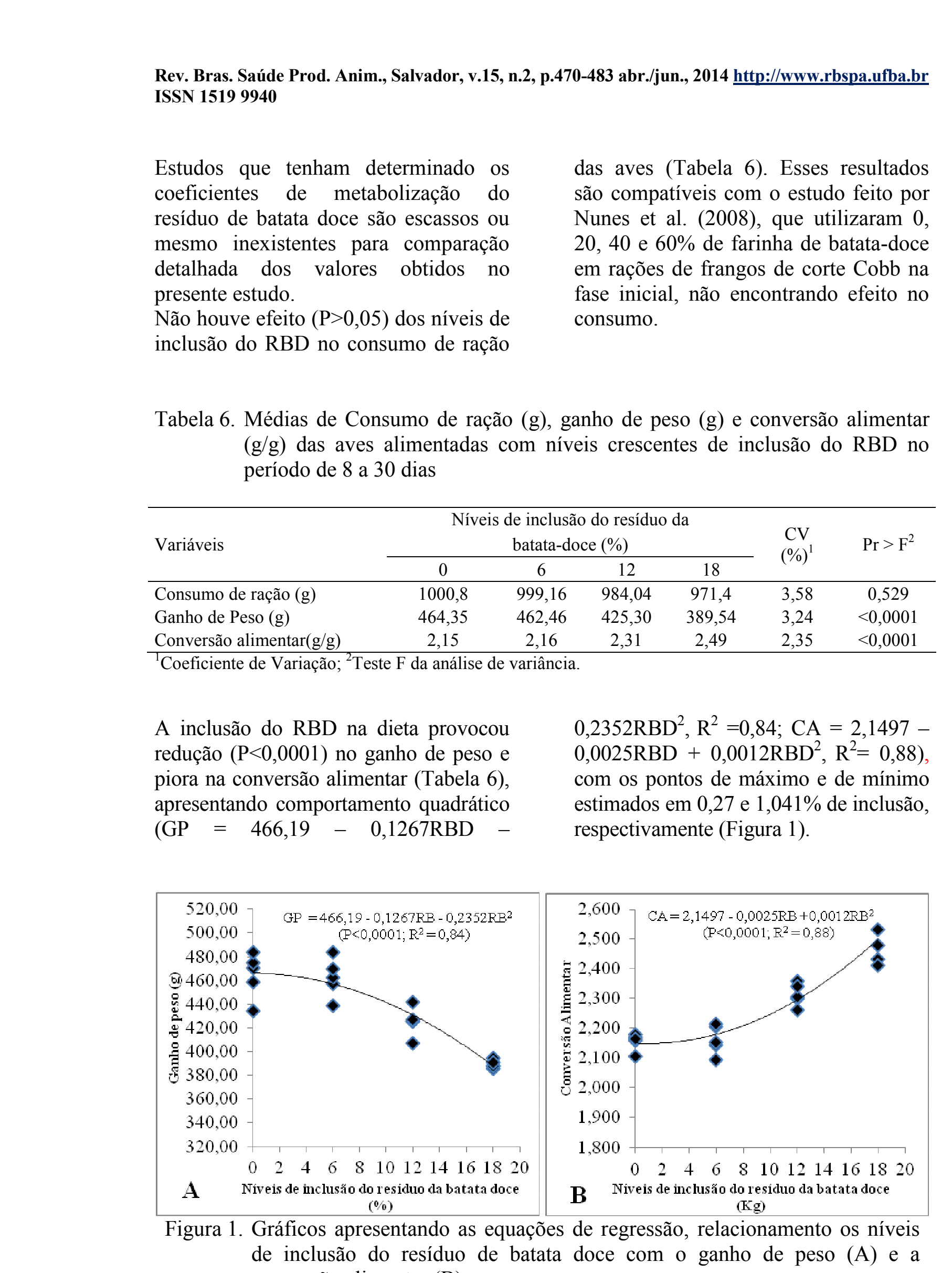

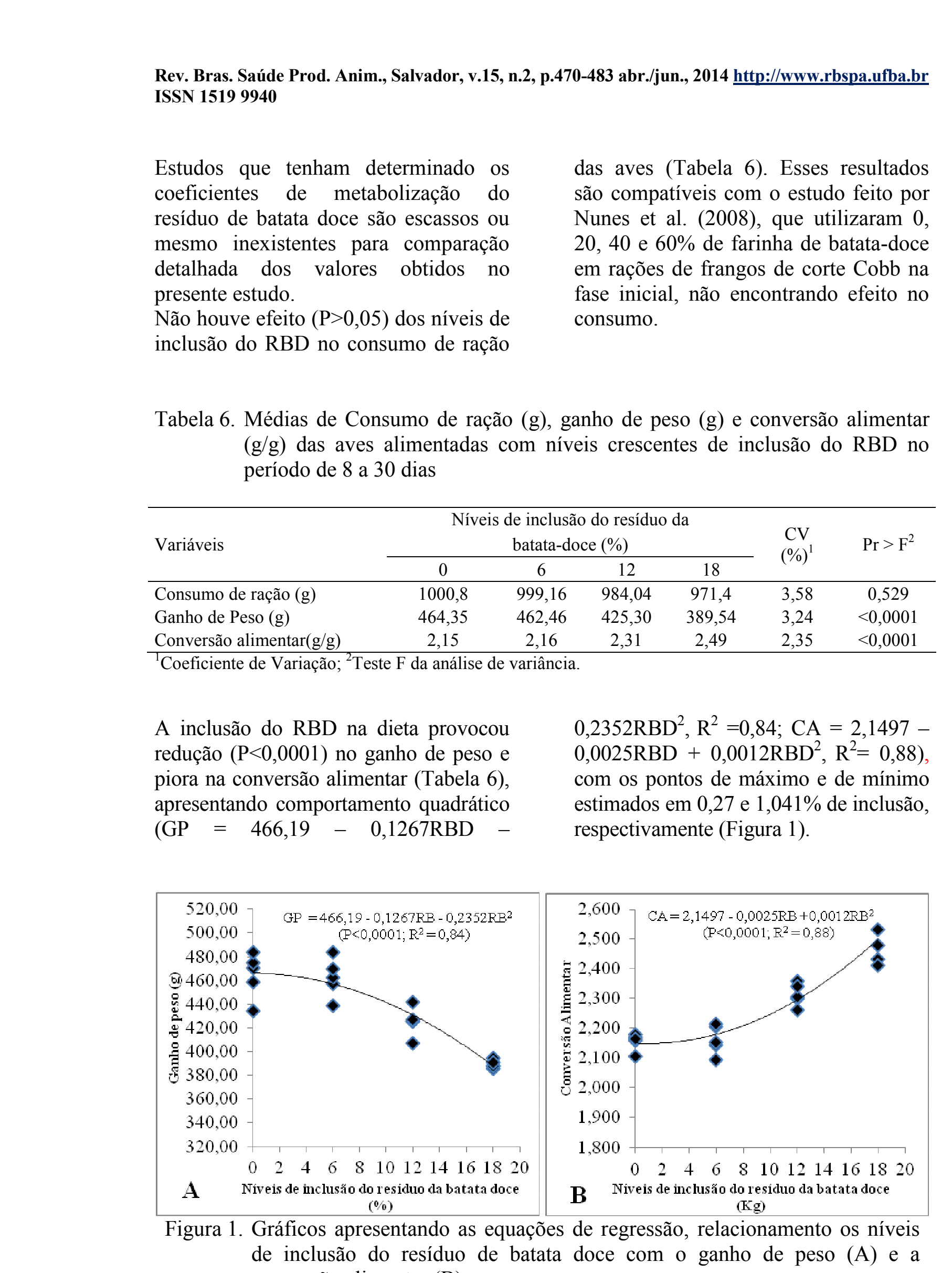

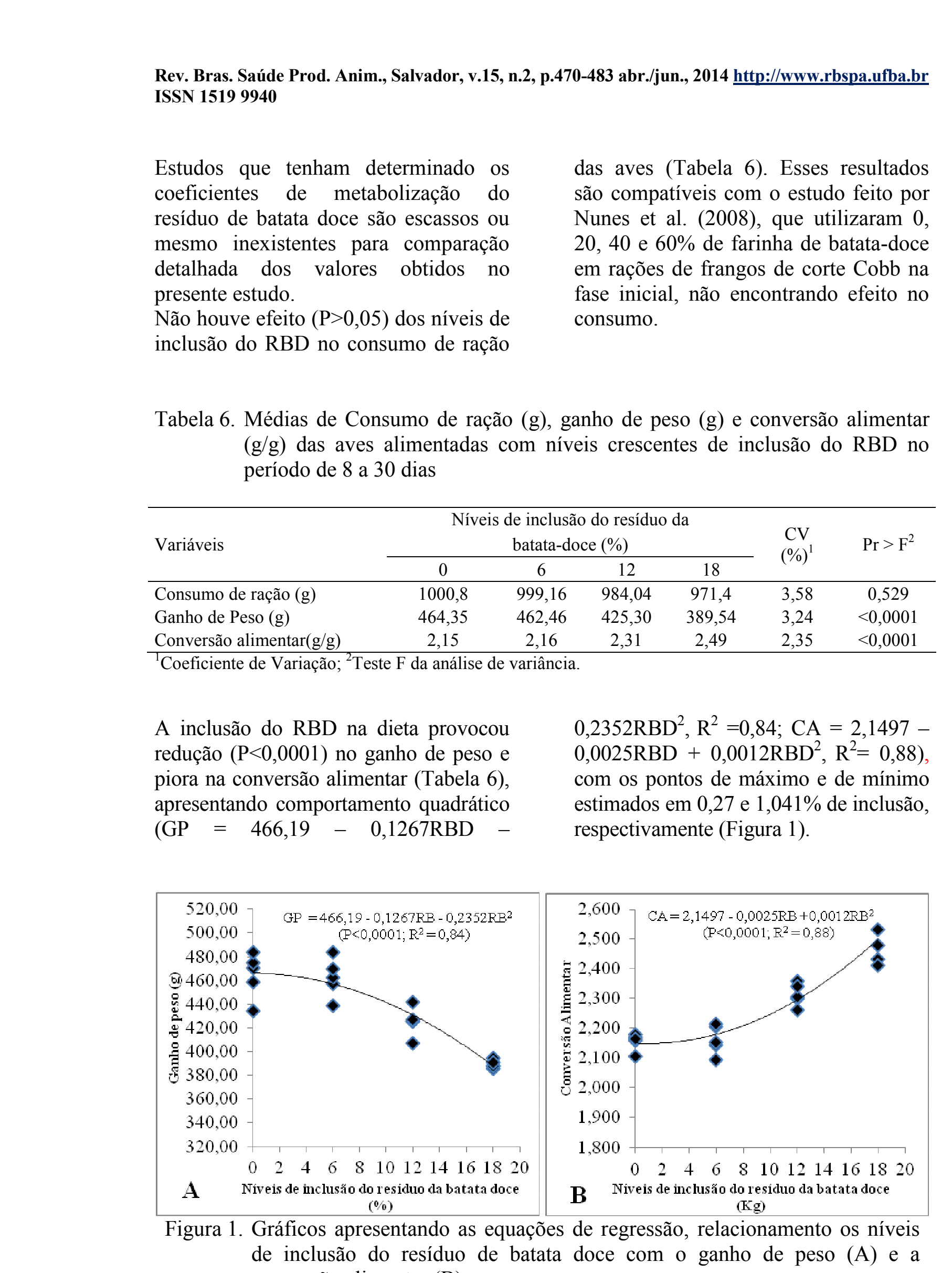

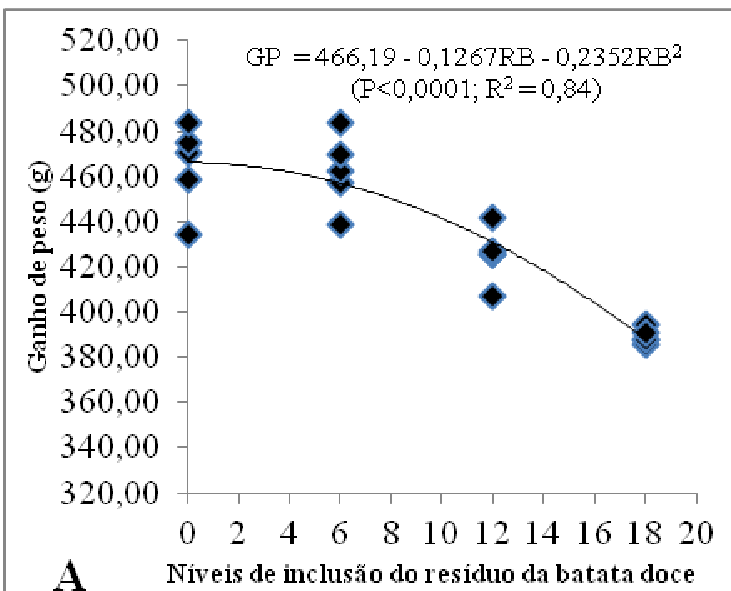
conversão alimentar (B)

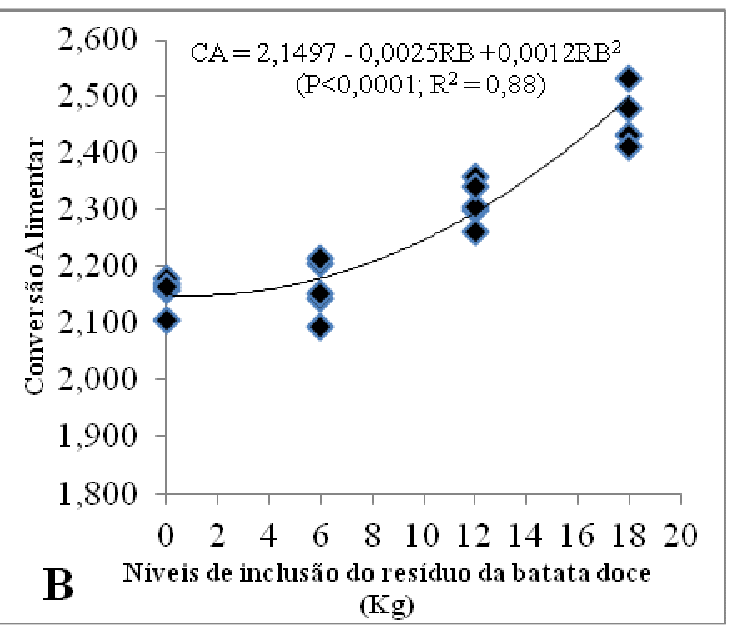

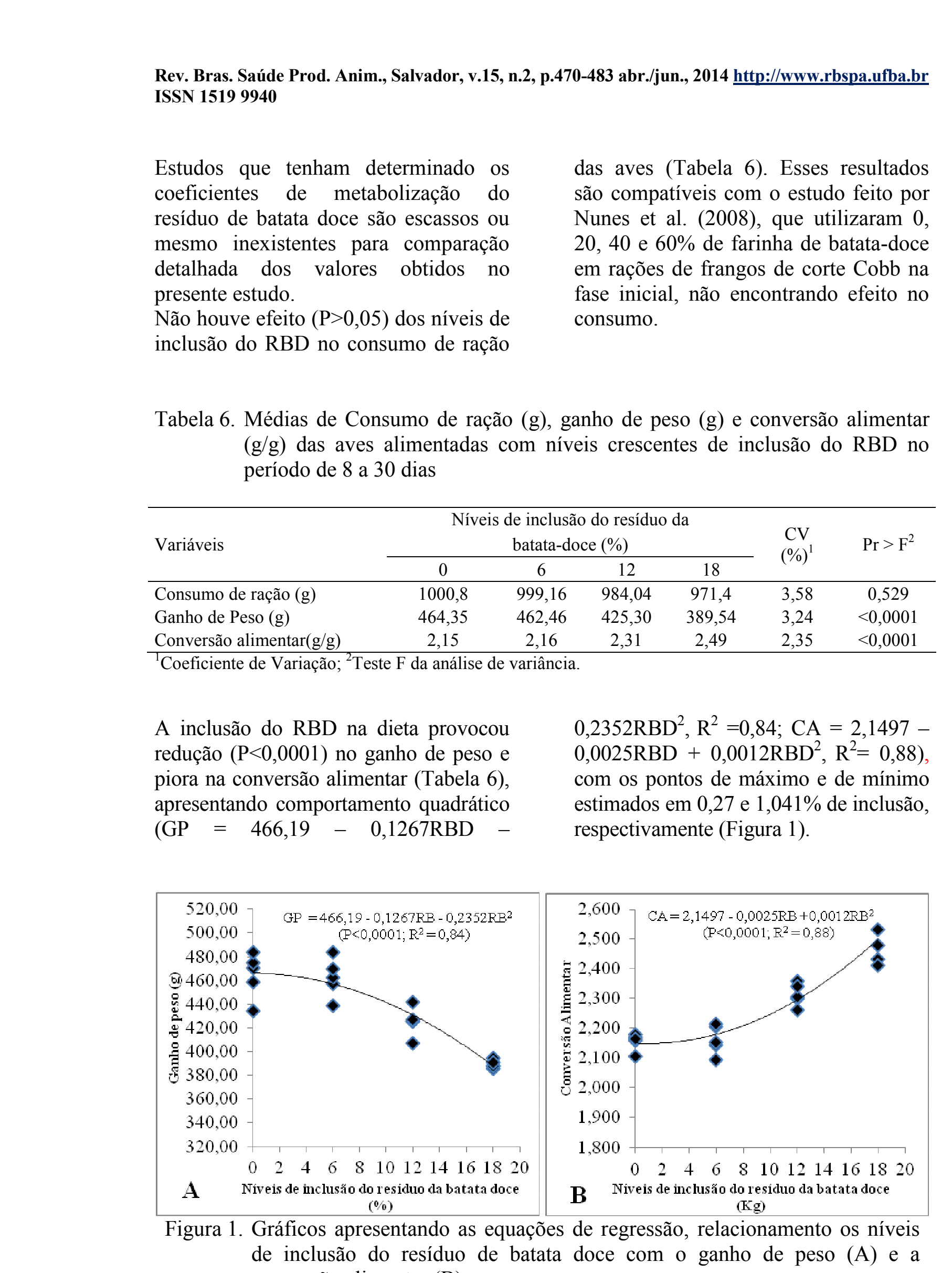

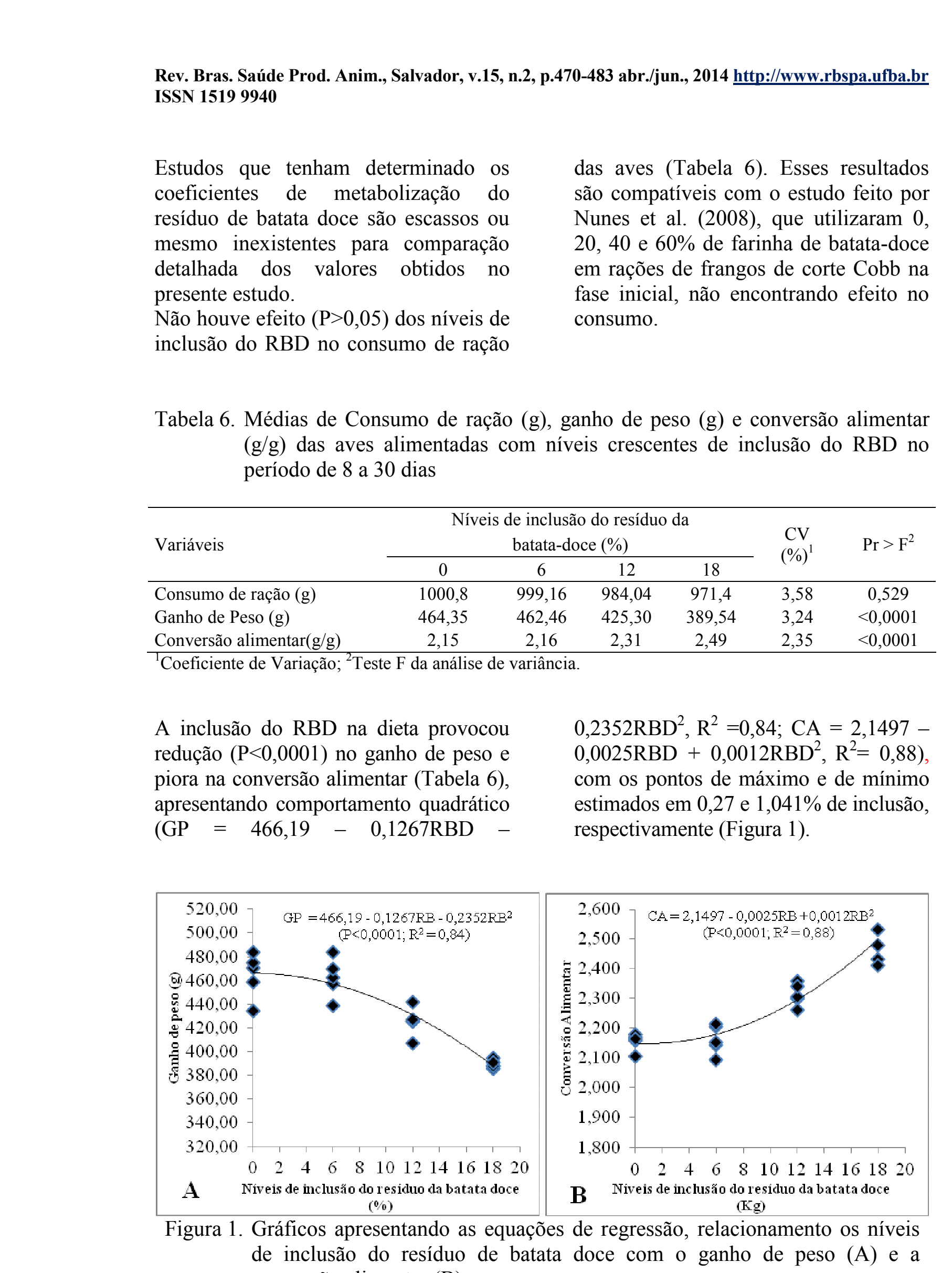

$$
\text { a }
$$


Resultados semelhantes foram encontrados por Maphosa et al. (2003) ao testarem $0 ; 25 ; 50 ; 75$ e $100 \%$ da batata-doce desidratada e moída em rações de frangos de corte nas fases inicial e terminação e observaram efeito negativo sobre o ganho de peso $\mathrm{e}$ conversão alimentar das aves em ambas as fases.

Por outro lado, Gerpacio et al. (1978) encontraram resultados divergentes ao avaliarem o desempenho de frangos de corte até seis semanas de idade utilizando $0,50,75$ e $100 \%$ de substituição do milho pela farinha da batata-doce nas rações. O desempenho das aves alimentadas com a batata-doce e, especialmente para os níveis mais elevados, foi menos satisfatório comparado com o milho, mas os autores sugeriram a substituição do milho pela batata-doce até $75 \%$.

A inclusão do RBD nas rações interferiu nos coeficientes de metabolização da matéria seca (CMMS), do extrato etéreo (CMEE), do nitrogênio (CMN), da energia bruta (CMEB), e a energia metabolizável aparente corrigida (EMAn) calculada para as rações experimentais (Tabela 7). O coeficiente de metabolização da fibra em detergente neutro (CMFDN) não foi afetado pelos tratamentos (Tabela 4).

Tabela 7. Efeito da inclusão do RBD nos coeficientes de metabolização da matéria seca (CMMS), extrato etéreo (CMEE), nitrogênio (CMN), energia bruta (CMEB), fibra em detergente neutro (CMF e a energia metabolizável aparente corrigida (EMAn)

\begin{tabular}{|c|c|c|c|c|c|c|}
\hline \multirow{2}{*}{ Item } & \multicolumn{4}{|c|}{ Níveis de inclusão do resíduo da Batata-doce (\%) } & \multirow{2}{*}{$\begin{array}{l}\text { CV } \\
(\%)\end{array}$} & \multirow{2}{*}{$\operatorname{Pr}>\mathrm{F}^{2}$} \\
\hline & 0 & 6 & 12 & 18 & & \\
\hline CMMS (\%) & 77,36 & 75,65 & 72,86 & 68,72 & 3,81 & 0,0050 \\
\hline CMEE $(\%)$ & 84,4 & 78,26 & 74,14 & 76,61 & 2,21 & $<0,0001$ \\
\hline CMN (\%) & 56,11 & 61,05 & 56,15 & 49,16 & 4,57 & 0,0002 \\
\hline CMEB (\%) & 80,08 & 77,55 & 74,9 & 68,18 & 4,10 & 0,0009 \\
\hline CMFDN $(\%)$ & 46,28 & 47,86 & 46,62 & 49,16 & 14,00 & 0,1200 \\
\hline EMAn (kcal/kg) & 3200 & 3062 & 2998 & 2745 & 3,86 & 0,001 \\
\hline
\end{tabular}

${ }^{1}$ Coeficiente de Variação; ${ }^{2}$ Teste F da análise de variância.

O coeficiente de metabolização da matéria seca (CMMS) das rações experimentais reduziu de forma linear $(\mathrm{CMMS}=77,95-0,48 \mathrm{R} ; \mathrm{P}=0,0003$; $\mathrm{R}^{2}=0,62$ ) com a inclusão do RBD (Figura 2). Como os nutrientes estão presentes na matéria seca do alimento, o decréscimo no índice de metabolizabilidade de matéria seca pode explicar a diminuição do aproveitamento de alguns nutrientes, justificando o menor ganho de peso a piora na conversão alimentar, tendo em vista a ausência de efeito no consumo de ração.

Em trabalho conduzido por Gerpacio et al. (1978), os autores sugeriram que a batata-doce possui fatores antinutricionais que inibem os processos digestivos e metabólicos, reduzindo a digestibilidade dos nutrientes e da energia.

O coeficiente de metabolização do extrato etéreo reduziu de maneira quadrática $(\mathrm{CMEE}=84,63-1,53 \mathrm{RBD}$ $\left.+0,06 \mathrm{RBD}^{2} ; \mathrm{P}<0,0001 ; \mathrm{R}^{2}=0,84\right) \mathrm{com}$ a inclusão do RBD com ponto de 
Rev. Bras. Saúde Prod. Anim., Salvador, v.15, n.2, p.470-483 abr./jun., 2014 http://www.rbspa.ufba.br ISSN 15199940

mínimo estimado em 12,75\%, tendo pequeno aumento a partir deste nível (Figura 2), possivelmente por efeito da adição de óleo de soja nas rações, visando o equilíbrio energético destas dietas (Tabela 2).

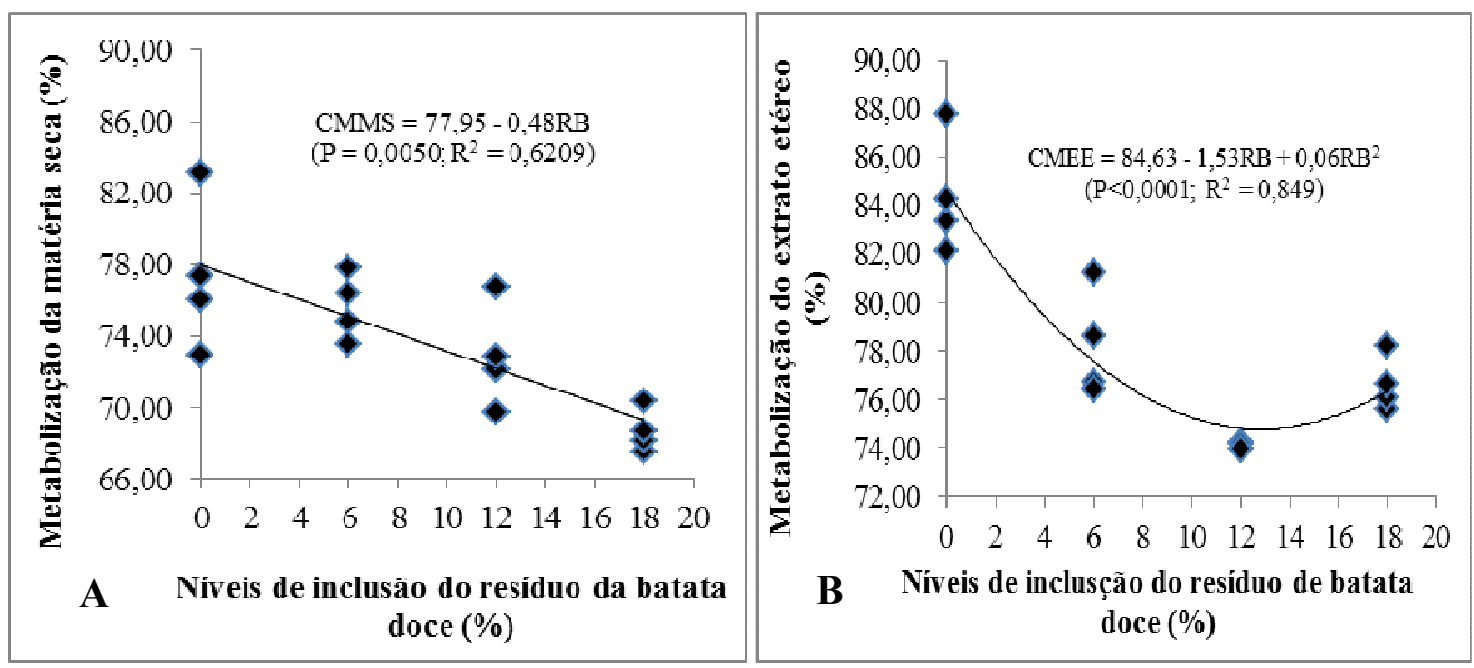

Figura 2. Gráficos apresentando as equações de regressão, relacionamento os níveis de inclusão do resíduo de batata doce com os coeficientes de metabolização da matéria seca (A) e extrato etéreo (B)

O coeficiente de metabolização do nitrogênio (CMN) apresentou comportamento quadrático $(\mathrm{CMN}=$ $56,50+1,060 \mathrm{RBD}-0,083 \mathrm{RBD}^{2} ; \mathrm{P}=$ 0,$0001 ; R^{2}=0,75$ ) (Figura 3), sendo os ponto de máximo estimado em $6,38 \%$. O máximo coeficiente de metabolização do nitrogênio das rações experimentais foi de 59,88\%, reduzindo com os demais níveis de inclusão do RBD, resultado semelhante ao encontrado por Tewe (1994), ao trabalhar com 50 e $100 \%$ de substituição do milho pela farinha de batata-doce seca ao forno, que obteve valores do coeficiente de metabolização do nitrogênio de 58,13 e $58,57 \%$, respectivamente.

Este mesmo autor, em outro ensaio, estudou diferentes níveis de substituição do milho pela farinha de batata-doce seca ao forno $(0,15$ e $30 \%)$ e dois níveis de energia na dieta $(2800$ e
$3000 \mathrm{kcal} / \mathrm{kg}$ ), encontrando o máximo coeficiente de metabolização de nitrogênio de $75,51 \%$ ao nível de $30 \%$ de substituição do milho pela farinha e $3000 \mathrm{kcal} / \mathrm{kg}$ de EM.

O coeficiente de metabolização da energia bruta (CMEB) e a energia metabolizável aparente corrigida (EMAn) reduziram de forma linear $(\mathrm{CMEB}=80,936-0,64 \mathrm{RBD} ; \mathrm{P}<0,0001$ $\left.; \mathrm{R}^{2}=0,68\right)$ e $($ EMAn $=3215,75-$ 23,82RBD; $\left.\mathrm{P}<0,0001 ; \mathrm{R}^{2}=0,68\right) \mathrm{com}$ o aumento dos níveis de inclusão do RBD (Figura 3).

O menor conteúdo de EMAn das rações a medida que os níveis de RBD foram sendo incrementados pode estar relacionado à redução do coeficiente de metabolização da matéria seca, indicando um pior aproveitamento dos nutrientes a medida que o alimento foi adicionado à dietas. 
Rev. Bras. Saúde Prod. Anim., Salvador, v.15, n.2, p.470-483 abr./jun., 2014 http://www.rbspa.ufba.br ISSN 15199940

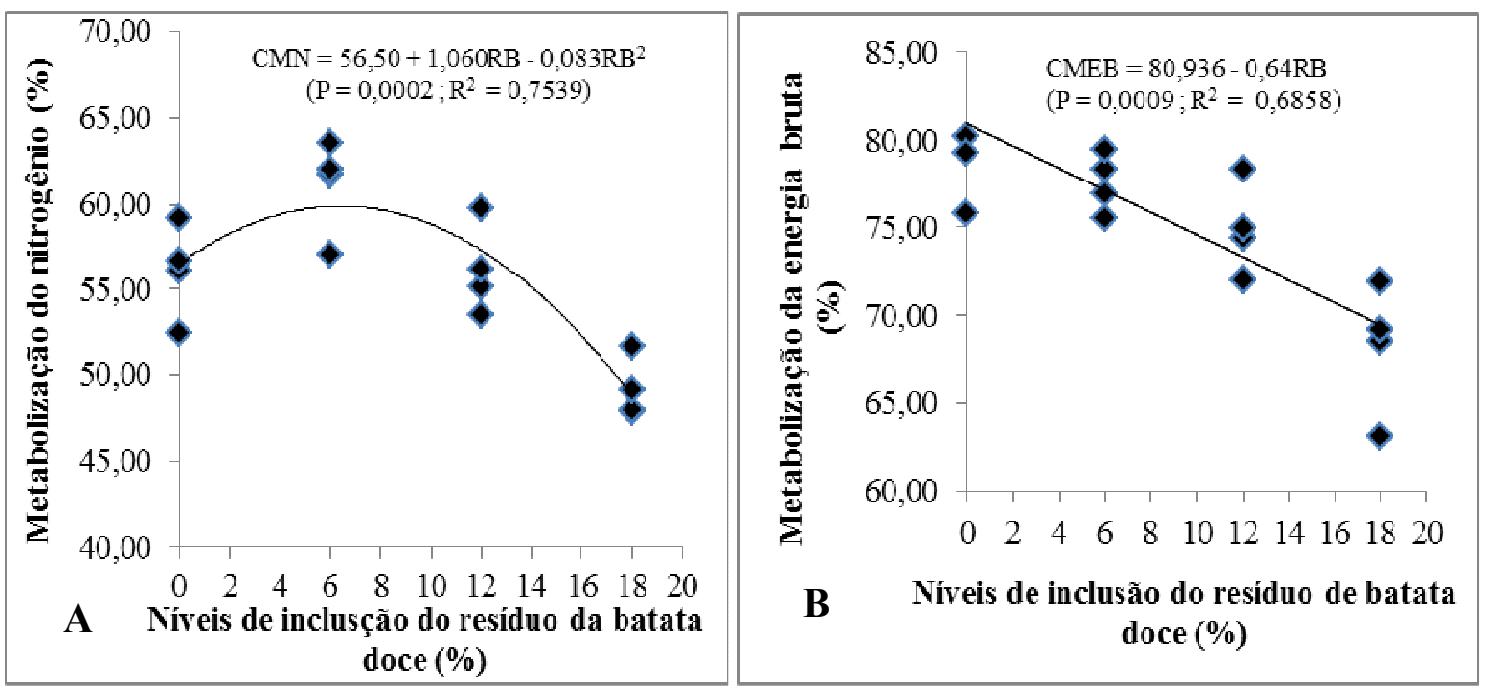

Figura 3. Gráficos apresentando as equações de regressão, relacionamento os níveis de inclusão do resíduo de batata doce com os coeficientes de metabolização do nitrogênio (A) e da energia bruta (B)

Apesar de se verificar o incremento nos teores de FDN das rações (Tabela 2) em função dos níveis de inclusão do resíduo de batata-doce, não houve diferença significativa no CMFDN, demonstrando que os animais excretaram o excesso de FDN consumido.

Segundo Classen (1996), a fibra alimentar em contato com a água funciona como barreira à ação hidrolítica das enzimas, dificultando o contato destas com os nutrientes, diminuindo o contato do bolo alimentar com as células absortivas da membrana intestinal.

Embora o RBD tenha apresentado composição nutricional com valores interessantes de energia bruta (Tabela 1), os resultados de desempenho $\mathrm{e}$ coeficientes de metabolização dos nutrientes mostraram que a inclusão do RBD afetou negativamente os resultados, com exceção do CMN.

Portanto o resíduo da batata-doce pode ser incluído em dietas de aves de crescimento lento sem afetar o desempenho e o metabolismo até $1,041 \%$.

\section{REFERÊNCIAS}

ALBINO, L.F.T.; FERREIRA, A.S.; FIALHO, CESAR,S.S. Determinação dos valores de energia metabolizável e matéria seca aparentemente metabolizável de alguns alimentos. Revista da Sociedade Brasileira de Zootecnia, v.11, n.2, p.207-221, 1982.

ALBINO, L.F.T.; FIALHO, E.T.; BLUME, E. Energia metabolizável e composição química de alguns alimentos para frangos de corte.

Revista da Sociedade Brasileira de Zootecnia, v.15, n.3, p.184-192, 1986.

ÁVILA, V.S.; PAULA, A.; BRUM, A.P.A.R.; COLDEBELLA, A.; MAIER, J.C. Determinação do período de coleta total de excretas para estimativa dos valores de energia metabolizável em frango de corte. Revista Brasileira de Zootecnia, v.35, n.5, p.1966-1979, 2006. 
Rev. Bras. Saúde Prod. Anim., Salvador, v.15, n.2, p.470-483 abr./jun., 2014 http://www.rbspa.ufba.br ISSN 15199940

BRUMANO, G.; GOMES, P.C.; ALBINO, L.F.T.; ROSTAGNO, H.S.; GENEROSO, R.A.R.; SCHMIDT, M. Composição química e valores de energia metabolizável de alimentos protéicos determinados com frangos de corte em diferentes idades. Revista Brasileira de Zootecnia, v.35, n.6, p.2297-2302, 2006.

CLASSEN, H.L. Cereal grain starch and exogenous enzymes in poultry diets. Animal Feed Science and Technology, v.62, n.1, p.21-27,1996.

FOOD AND AGRICULTURA ORGANIZATION - FAO, 2008.

Cassava. Disponível em:

$<$ http://www.fao.org/docrep/011/ai474e/ ai474e06.htm>. Acesso em: 25 jan. 2010.

FREITAS, E.R.; SAKOMURA, N.K.; NEME, R.; SANTOS, A.L.; FERNANDES, J.B.K. Efeito do processamento da soja integral sobre a energia metabolizável e a digestibilidade dos aminoácidos para aves. Revista Brasileira de Zootecnia, v.34, n.6, p.1948-1949, 2005.

GERPACIO, A.L.; PASCUAL, F.S.D.; QUERUBIN, L.J.; VERGEL DE DIOS, A.F.; MERCADO, C.I. Evaluation of tuber meals as energy sources. Sweet potato and cassava based rations for broilers. Philippine Agriculturalist, v.61, n.9-10, p.395-410, 1978.

GOMES, F.A.; FASSANI, E.J.; RODRIGUES, P.B.; SILVA FILHO, J.C. da. Valores energéticos de alguns alimentos utilizados em rações para codornas japonesas. Revista Brasileira de Zootecnia, v.36, n.2, p.396-402, 2007.
MAPHOSA, T.; GUNDUZA, K.T.; KUSINA, J.; MUTUNGAMIRI, A. Evaluation of sweet potato tuber (Ipomea batatas 1.) as a feed ingredient in broiler chicken diets; Livestock Research for Rural Development, v.15, n1, 2003. Disponível em http://www.lrrd.org/lrrd15/1/maph151.ht $\mathrm{m}$. Acessado em: 15 de dezembro de 2009.

MATTERSON, L.D.; POTTER, L.M.; STUTZ, M.W.; SINGSEN, E.P. The metabolizable energy of feed ingredients for chickens. Research Report, n.7, p311, 1965.

MELO, H.H.C; GOMES, P.C; ROSTAGNO, H.S; ALBINO, L.F.T; SOUZA, R.M; CALDERANO, A.A. Valores de energia metabolizável de alguns alimentos obtidos com aves de diferentes idades. Revista Brasileira de Zootecnia, v.38, n.5, p.863-868, 2009.

NASCIMENTO, G.A.J.; COSTA F.G.P.; JÚNIOR, V.S.A.; BARROS, L.R. Efeitos da substituição do milho pela raspa de mandioca na alimentação de frangos de corte, durante as fases de engorda e final. Ciência e

Agrotecnologia, v.29, n.1, p.200-207, 2005.

NERY, L.R.; ALBINO, L.F.T.; ROSTAGNO, H.S.; CAMPOS, A.M.A.; SILVA, C.R. Valores de energia metabolizável de alimentos determinados com frangos de corte. Revista Brasileira de Zootecnia, v.36, n.5, p.1354-1358, 2007.

NUNES, J.K.; PROVENCI, M.; WULFF, M.L.; HENRICH, L.A.; GONÇALVES, F.M.; DALLMANN, H.M.; GENTILINI, F.P.; LOPES, D.N.; ANCIUTI, M.A.; MAIER, J.C.; RUTZ, F. Desempenho produtivo de frangos de corte alimentados com Farinha de batatadoce, na fase inicial. In: Congresso de 
Rev. Bras. Saúde Prod. Anim., Salvador, v.15, n.2, p.470-483 abr./jun., 2014 http://www.rbspa.ufba.br ISSN 15199940

iniciação científica, X Encontro de Pósgraduação, 17., 2008, Pelotas, RS.

Anais... Pelotas, RS, 2008.

PASCOAL, L.A.F; BEZERRA, A.P.A; GONÇALVES, J.S. Farelo de babaçu: valor nutritivo e utilização na alimentação animal. Revista Eletrônica Nutritime, v.3, n 4, p.339-345, 2006.

PELIZER, L.H.; PONTIER, M.H.; MORAIS, T. de O. Utilização de resíduos agroindustriais em processos biotecnológicos como perspectiva de redução do impacto ambiental. Jornal Technology Managemente \& Innovation, v.1, n.1, p.118-124, 2007.

RIZZI, C.; MARANGON, A.; CHIERICATO, G.M. Effect o genotypeon slaughtering performance and meat physical and sensory characteristics of organic laying hens. Poultry Science, v.86, p.128-135, 2007.

RODRIGUES, P.B.; MARTINEZ, R.S.; FREITAS, R.T.R.; BERTECHINI, A.G.; FIALHO, E.T. Influência do tempo de coleta e metodologias sobre a digestibilidade e o valor energético de rações para aves. Revista Brasileira de Zootecnia, v.34, n.3, p.882-889, 2005.

RODRIGUES, L.G.S.M.; RODRIGUES, F.M. Composição química bromatológica do resíduo de biocombustível de batata-doce (Ipomoea batatas (lam)). Enciclopédia Biosfera, Centro Científico Conhecer, v.8, n.14, p.234-245, 2012.

ROSTAGNO, H.S.; ALBINO, L.F.T.; DONZELE, J.L.; GOMES, P.C.; OLIVEIRA, R.F.; LOPES, D.C.; FERREIRA, A.S.; BARRETO, S.L.T.; EUCLIDES, R.F. Tabelas brasileiras para aves e suínos: composição de alimentos e exigências nutricionais. Viçosa, MG; Universidade Federal de Viçosa, 2011. 252p.
ROSTAGNO, H.S.; ALBINO, L.F.T.; DONZELE, J.L.; GOMES, P.C.;

OLIVEIRA, R.F.; LOPES, D.C.; FERREIRA, A.S.; BARRETO, S.L.T.

Tabelas Brasileiras para Aves e Suínos: composição de Alimentos e Exigências Nutricionais. 2.ed. Viçosa, MG; Universidade Federal de Viçosa, 2005. 186p.

SAKOMURA, N.K.; ROSTAGNO, H.S. Metodologias para avaliar o conteúdo de energia dos alimentos. In:

SAKOMURA, N.K.; ROSTAGNO, H.S. Métodos de pesquisa em pesquisa em nutrição de monogástricos. Jaboticabal: Universidade Estadual Paulista, 2007. p.41 - 90,

SIBBALD, I.R.; SLINGER, S.J. A biological assay for metabolizable energy in poultry feed ingredients together with findings which demonstrate some of the problems associated with the evaluation of fats. Poultry Science, v.42, n.2, p.313-325, 1963.

SIBBALD, I.R. A bioaasay for the true metabolizable energy in feedstuffs.

Poultry Science, v.55, n.1, p.303-308, 1976.

SANTOS NETA, E.R.; VAZ, R.G.M.V.; RODRIGUES, K.F.; SOUSA, J.P.L.; PARENTE, I.P.; ALBINO, L.T. ; SIQUEIRA, J.C.; ROSA, F.C. Níveis de inclusão da torta de babaçu em rações de frangos de corte na fase inicial. Revista Brasileira de Saúde Produção Animal [online], v.12, n.1, p.234-243, 2011.

SILVEIRA, M.A.; DIAS, L.E.; ALVIM, T.C.; TAVARES, I.B.; SANTANA, W.R.; SOUZA, F.R. A cultura da batata-doce como fonte de matéria prima para o etanol. Palmas: Universidade Federal do Tocantins, 2008. 64p. (Boletim Técnico). 
Rev. Bras. Saúde Prod. Anim., Salvador, v.15, n.2, p.470-483 abr./jun., 2014 http://www.rbspa.ufba.br ISSN 15199940

SILVA, D.J.; QUEIROZ, A.C. Análise de alimentos: métodos químicos e biológicos. 3.ed. Viçosa, MG:

Universidade Federal de Viçosa, 2006. $235 p$.

SOUSA, J.P.; RODRIGUES, K.F.; ALBINO, L.F.T.; SANTOS NETA, E.R.; VAZ, R.G.M.V.; PARENTE, I.P.; SILVA, G.F.; AMORIM, A.F. Bagaço de mandioca em dietas de frangos de corte. Revista Brasileira de Saúde e Produção Animal [online], v.13, n.4, p.1044-1053, 2012.

STATISTICAL ANALYSES SYSTEM. SAS/INSIGHT User's guide. Version 9.0. Cary: SAS Institute, 1998.
TAKAHASHI, S.E.; MENDES, A.A.; SALDANHA, E.S.P.B.;

PIZZOLANTE, C.C.K.; PELÍCIA, K.; GARCIA, R.G.; PAZ, I.C.L.A.; QUINTEIRO, R. R. Efeito do sistema de criação sobre o desempenho e rendimento de carcaça de frangos de corte tipo colonial. Arquivo Brasileiro de Medicina Veterinária e Zootecnia, v.58, n.4, p.624-632, 2006.

TEWE, O.O. Sweet potato utilization in poultry diets. Acta Horticulturae, v.380, p.426-437, 1994.

Data de recebimento: 16/05/2013

Data de aprovação: 26/06/2014 